\title{
Volcanology and Archaeology for Better Understanding the History of Campi Flegrei: Post-NYT Bradyseisms and More Rapid Deformation
}

\author{
Angelo Paone, Sung-Hyo Yun \\ Department of Earth Science Education, Pusan National University, Busan, Republic of Korea \\ Email: angelo.paone1@gmail.com
}

How to cite this paper: Paone, A. and Yun, S.-H. (2018) Volcanology and Archaeology for Better Understanding the History of Campi Flegrei: Post-NYT Bradyseisms and More Rapid Deformation. Open Journal of Geology, 8, 201-221. https://doi.org/10.4236/ojg.2018.83013

Received: January 18, 2018

Accepted: March 9, 2018

Published: March 12, 2018

Copyright $\odot 2018$ by authors and Scientific Research Publishing Inc. This work is licensed under the Creative Commons Attribution International License (CC BY 4.0).

http://creativecommons.org/licenses/by/4.0/

\section{(c) (i) Open Access}

\begin{abstract}
The Campi Flegrei volcanic district includes insular (Ischia and Procida Islands) and peninsular volcanic activity (Campi Flegrei volcanic field) with the link to older activity till Ponza Island. The history of this area has been studied in detail since the eruption of the Campanian Ignimbrite (CI, age: $39 \mathrm{ky}$ BP, volume: $200-300 \mathrm{~km}^{3}$ ), which makes this one of the most powerful eruptions in Europe. In the Neapolitan Yellow Tuff (NYT: age: 15.0 ky BP, volume: $50 \mathrm{~km}^{3}$ ), another powerful eruption occurred. Activity younger than the NYT can be subdivided in three epochs which include 70 recognized ephemeral eruptions. The volume of these individual eruptions is between 0.4 and $1 \mathrm{~km}^{3}$ (DRE). Probably, the long-lasting magma reservoirs (i.e., CI and NYT) represent eruptions that are fed by deep magma reservoirs. In deep reservoirs $(>10 \mathrm{~km})$, magmas stagnate, differentiate and are probably modified by crustal components (Hercynian basement). The long-lasting reservoirs are also the ones that feed the ephemeral shallow magmatic system $(2-5 \mathrm{~km})$ that gave rise to the post-caldera magmatic epochs. However, the magmas of the post-caldera epochs are isotopically heterogeneous and made by several components (i.e., least evolved (as an example the Minopoli eruption, 9500 y BP), $\mathrm{CI}$, and NYT components). Mixing between ephemeral shallow reservoirs occurs. Mixing of long lasting reservoirs also occurs; and also during explosive eruptions. The concentration of earthquakes and the deformation history suggest that Campi Flegrei could erupt again with an ephemeral eruption, especially if the uplift will reach 5 - $6 \mathrm{~m}$ like Monte Nuovo eruption, given existing uplift of 1970-72 and 1983-84.
\end{abstract}

\section{Keywords}

Phlegraean Fields, Volcanoes, Bradyseism, Volcano-Stratigraphy, Archeology 


\section{Introduction}

Campi Flegrei (Figure 1) was named after the Greek settlement around Naples and in particular on the Islands of Procida and Ischia as "Campi Ardenti". Probably, their settlement began $4-5 \mathrm{ka}$ in the $3^{\circ}$ epoch of activity of Campi Flegrei [1] [2]. In the world, Campi Flegrei can be compared to Rabaul volcanic field and Yellowstone volcanic field. One characteristic is the deformation of the land, rising and sinking through time. This characteristic feature is called Bradyseism; it is well measured in Campi Flegrei through benchmarks which are remeasured regularly. Campi Flegrei is just a little piece in an area larger that goes from Campi Flegrei to Roccamonfina volcano including larger volcanic area (Ponza, Ventotene), volcanic field from Gaeta to Ischia, submerged below sea level (Figure 2), with ages from 1 - 5 Ma up to now [3] [4].

Uncertainness about the cause(s) of deformation remain, specifically on the relative roles of magma at $3-4 \mathrm{~km}$ deep and aqueous fluid tapped by silt and clay that cap the exit to the magma but influence the deformation in Campi Flegrei [5]. I will try to trace the volcanic history versus the deformation history to address this question. The deformation history can be very important to: (a) understand the cause of deformation (fluid versus magma), (b) forecast the volcanic scenario of the next eruption.

\section{Chronology of the Campi Flegrei}

The chronology that will be analyzed goes from $60 \mathrm{Ka}$ to up to now (Figure 3). Since the beginning of the century, the scientists have studied the chronostratigraphy of Campi Flegrei [6] [7] [8] [9] [10]. The new improved post-NYT stratigraphy of Campi Flegrei has been made by [11] (Figure 3). In this list are

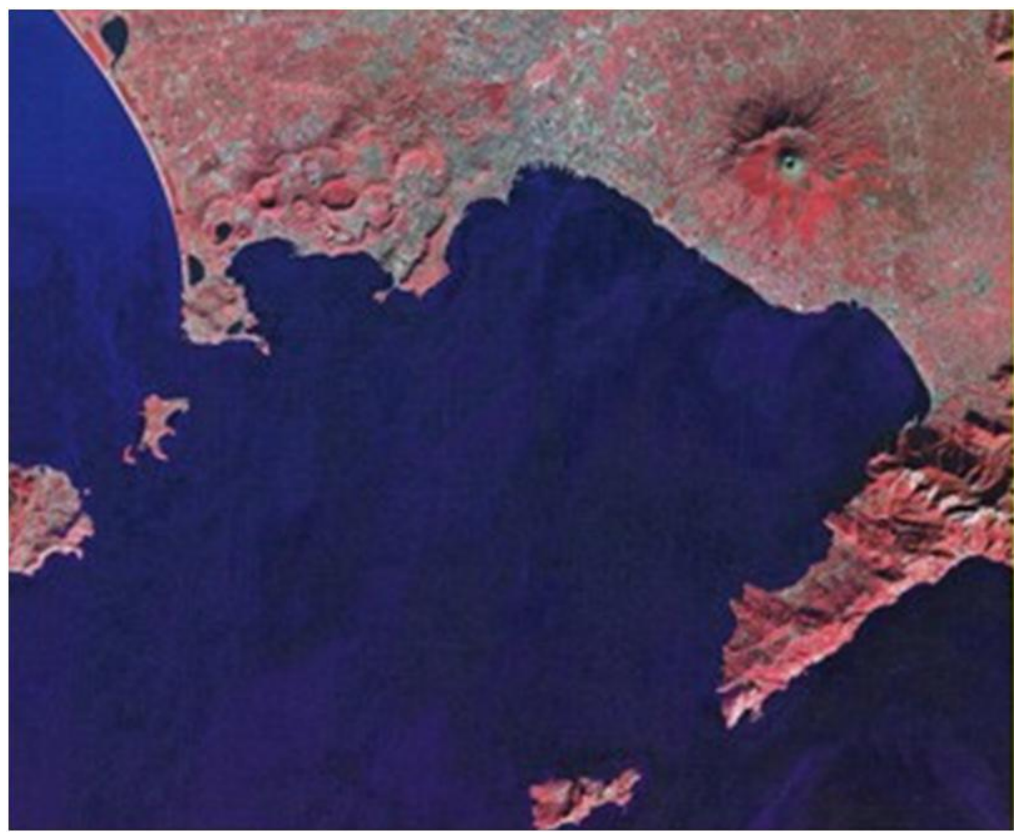

Figure 1. Satellite image of Naples, Campi Flegrei e Somma-Vesuvius. 


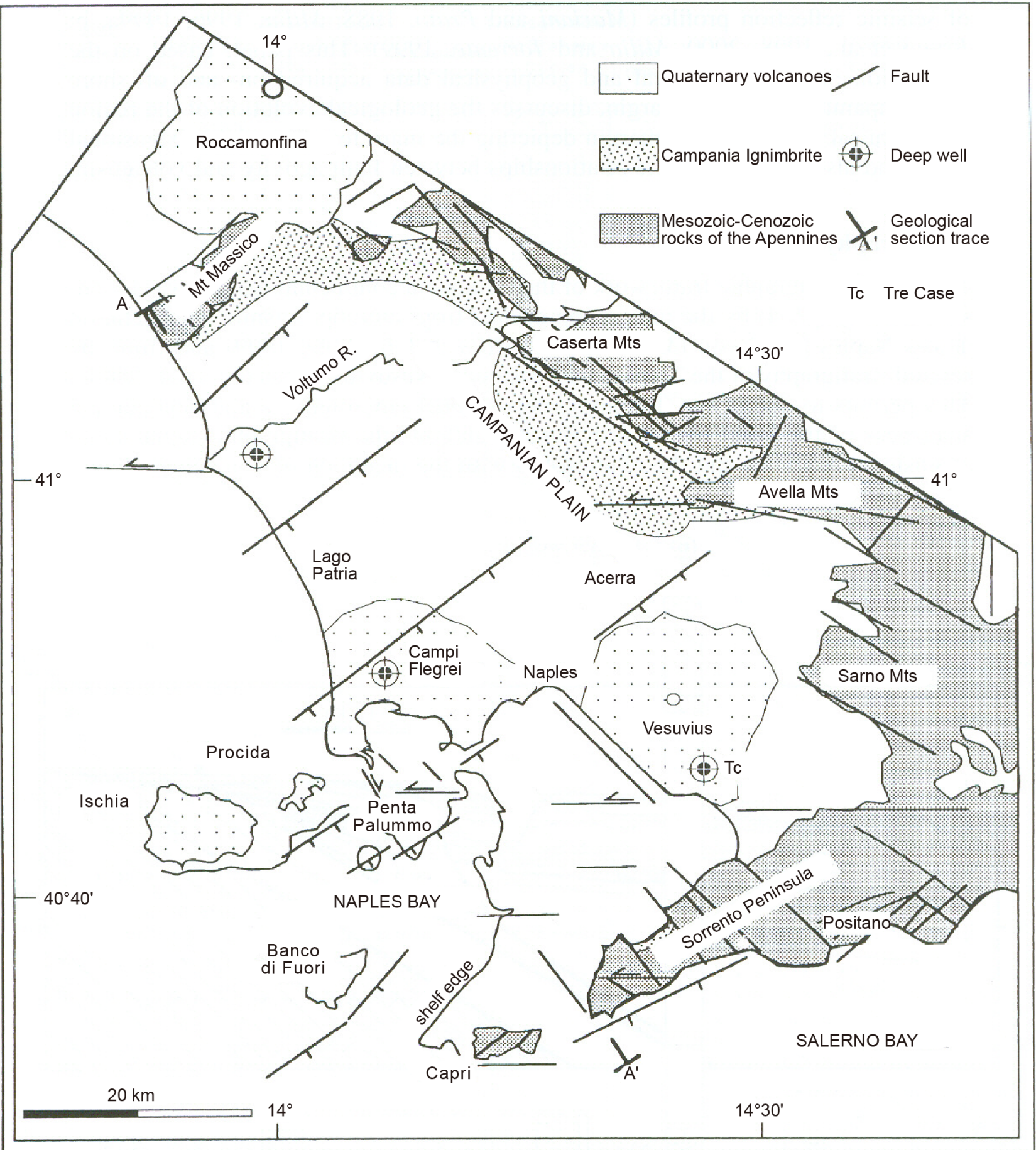

Figure 2. Simplified geological map of Campania plain.

included: volcanoes and tephra with their vents. Numbers mean single tephra layers.

Epoch I (15 - $9.5 \mathrm{ka})$ : Rione Terra, La Pietra, Capo Miseno, Porto Miseno, Bacoli Bellavista, Torre Cappella, Gauro, Archiaverno, Mofete, La Pigna 1, 2, 3; Minopoli, 1, 2; Pomici Principali, Soccavo 1, 2, 3, 4; Pisani 1, 2; Montagna Spaccata, Fondo Riccio, Concola. 


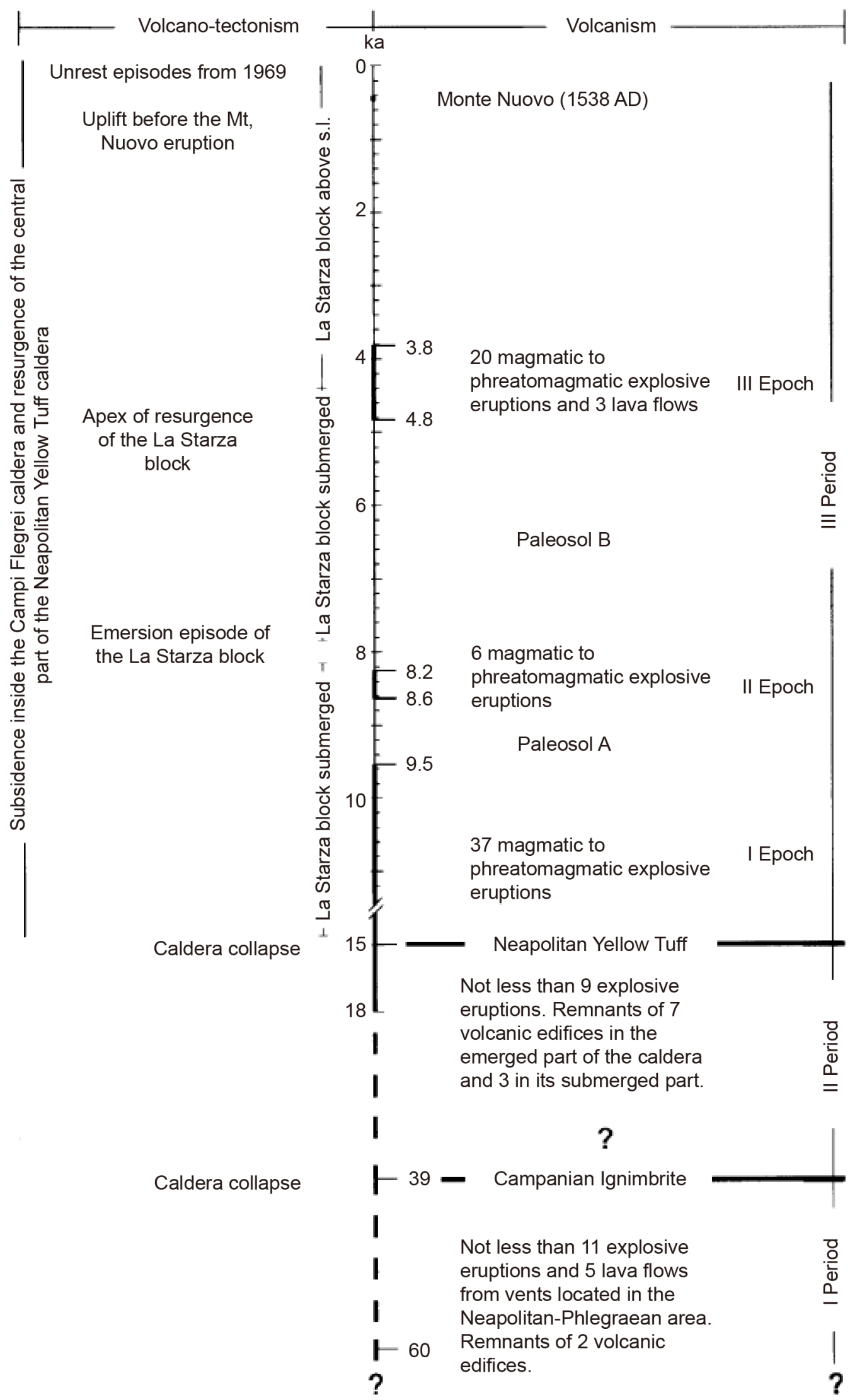

Figure 3. Chronology of Campi Flegrei from $60 \mathrm{Ka}$ to now (from [1]). 
Epoch II (8.6 - 8.2 ka): Fondi di Baia, Sartania 1, 2; Costa S. Domenico, S. Martino.

Epoch III (4.8 - 3.8 ka): Nisida, Banco di Nisida, Monte Spina lavas, Agnano 1, 2, 3; Averno 1, 2; Cigliano 1, Pignatiello 2; Mt. St. Angelo, Paleo Astroni 1, 2, 3; Agnano Mt. Spina, Fossa Lupara (3.8 ka).

Two largest events are Campanian Ignimbrite (39 ka, from [12]) and the NYT eruption (15 ka from [13]), with volume $200-300 \mathrm{Km}^{3}$ for CI and $50 \mathrm{~km}^{3}$ for NYT. From Figure 3 we can understand the ratio between the eruptions and inter-eruption activity within the Campi Flegrei during $15 \mathrm{ka}$ [2]. The last eruption occurred in the 1538 forming a cinder cone called Monte Nuovo. It is the youngest cone of Campi Flegrei. On the other hand, there is a large dome called Mt. Olibano (Accademia Aeronautica). The only large effusive structure in the Campi Flegrei.

\section{Some Information on Campanian Ignimbrites (CI) and Neapolitan Yellow Tuff (NYT)}

Figure 4(a) shows an impressive outcrop of Breccia, named Breccia Museo. This type of deposit is a lag-breccia in Ignimbrite, deposited near its source caldera. This kind of deposit contradicts the idea of the Ignimbrite pipe caldera and which has been inferred east of Campi Flegrei within the center of Naples, where people do not see any type of Breccia Museo. Figure 4(b), Figure 4(c), show the Ignimbrite (CI) and the Neapolitan Yellow Tuff (NYT). These outcrops are sitting in a position far from Campi Flegrei. While CI has climbed the Apennine the NYT has covered all the Napoli City in fact after the excavation by Romans now this part of Napoli can be visited in the commercial caves from tourists looking all the beauty of NYT. Costa et al. [14] use a novel method to quantify and reproduce the CI tephra deposit, applying a computational ash dispersion model combined with the analysis of a set of wind fields, and more than 100 thickness measurements of the CI tephra deposit declare that the CI is a super-eruption and the origin is from the Campi Flegrei. The distal tephra show again that the volcanic product of CI must originate in the Campi Flegrei. Figure 5 show how the thickness of the CI increase getting close to Campi Flegrei. This pose two controversy (a) CI is originate in Campi Flegrei, and CI is not a super-eruption. [15] state the magnitude of CI is 7.7 suggestive of a Collosal eruption. $\mathrm{CI}$ and NYT have difference in $\mathrm{Sr}-\mathrm{Nd}-\mathrm{Pb}$ isotopic variation together with Minopoli (ephemeral single eruption). This heterogeneity suggest that mostly of the activity after the largest eruptions (CI, NYT) derive by mixing from their magmas from the Deep and Hot Intrusion Zone [16] [17] [18]; Paone (unpublished data).

\section{Deformation Types: Bradyseism and Short-Lived}

After the collapse of NYT, Campi Flegrei has started a long history of deformation. It is useful to differentiate two types of deformation-short, within the 


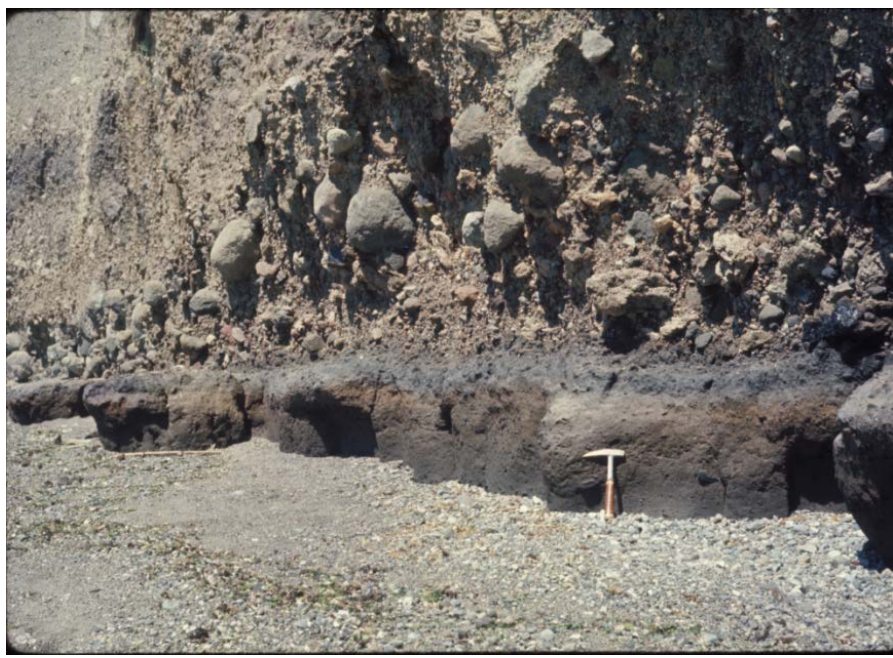

(a)

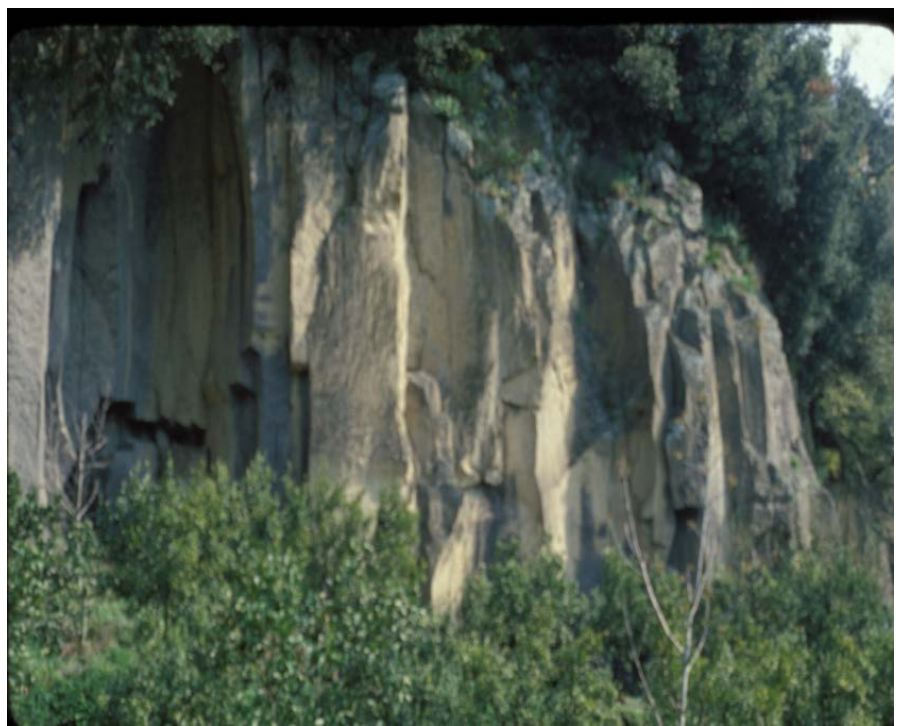

(b)

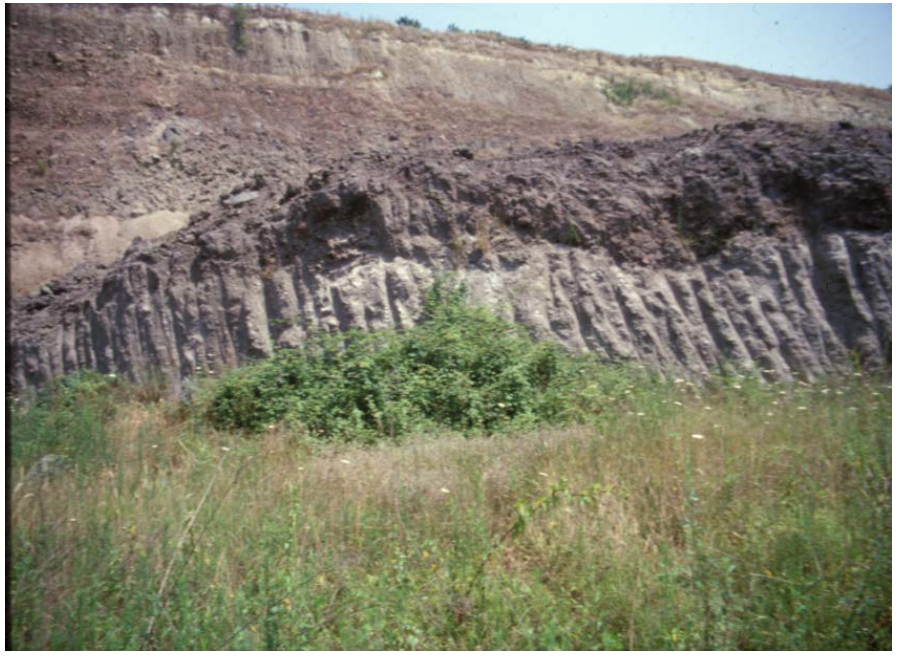

(c)

Figure 4. (a) Breccia Museo; (b) Lithotype of CI; (c) Lithotype of NYT. 


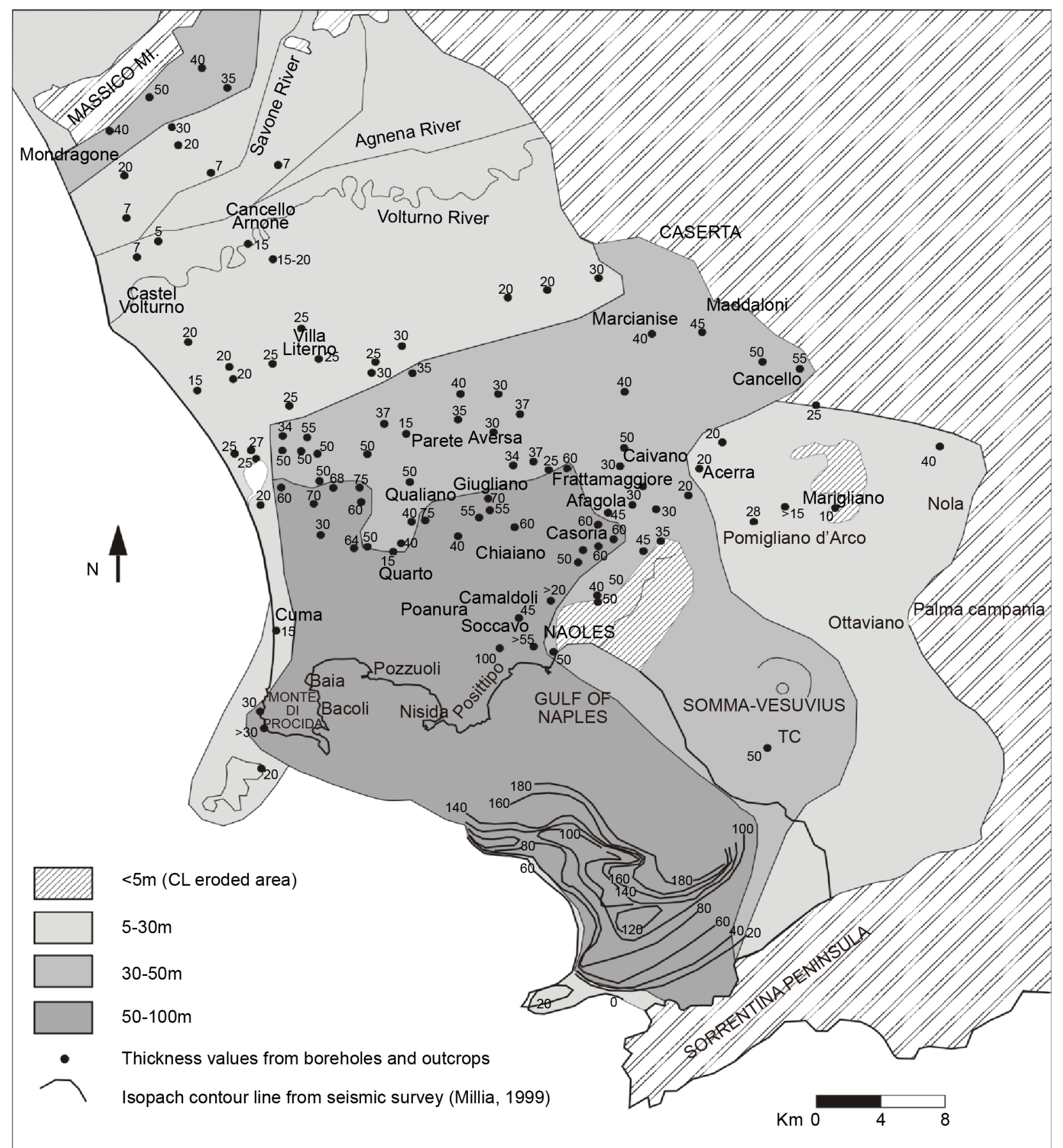

Figure 5. Thickness of the CI from boreholes and outcrops.

eruptive Epochs and long, outside the Epochs. The deformations can be traced by different reference points: pavement of Serapide temple the three column of $\mathrm{CaCO}_{3}$-marble, Ponte of Caligola, and Santa Maria delle Grazie Church' pavement. Moreover, the distribution of the vents in the last 15 ka suggests that they are governed by NYT caldera for each epoch (Figure 6). The area most dangerous is Astroni-Agnano-Monte Spina. Another site to consider is the area of the Averno lake (Maar structure), This must be an area at high risk of eruption [1]. 


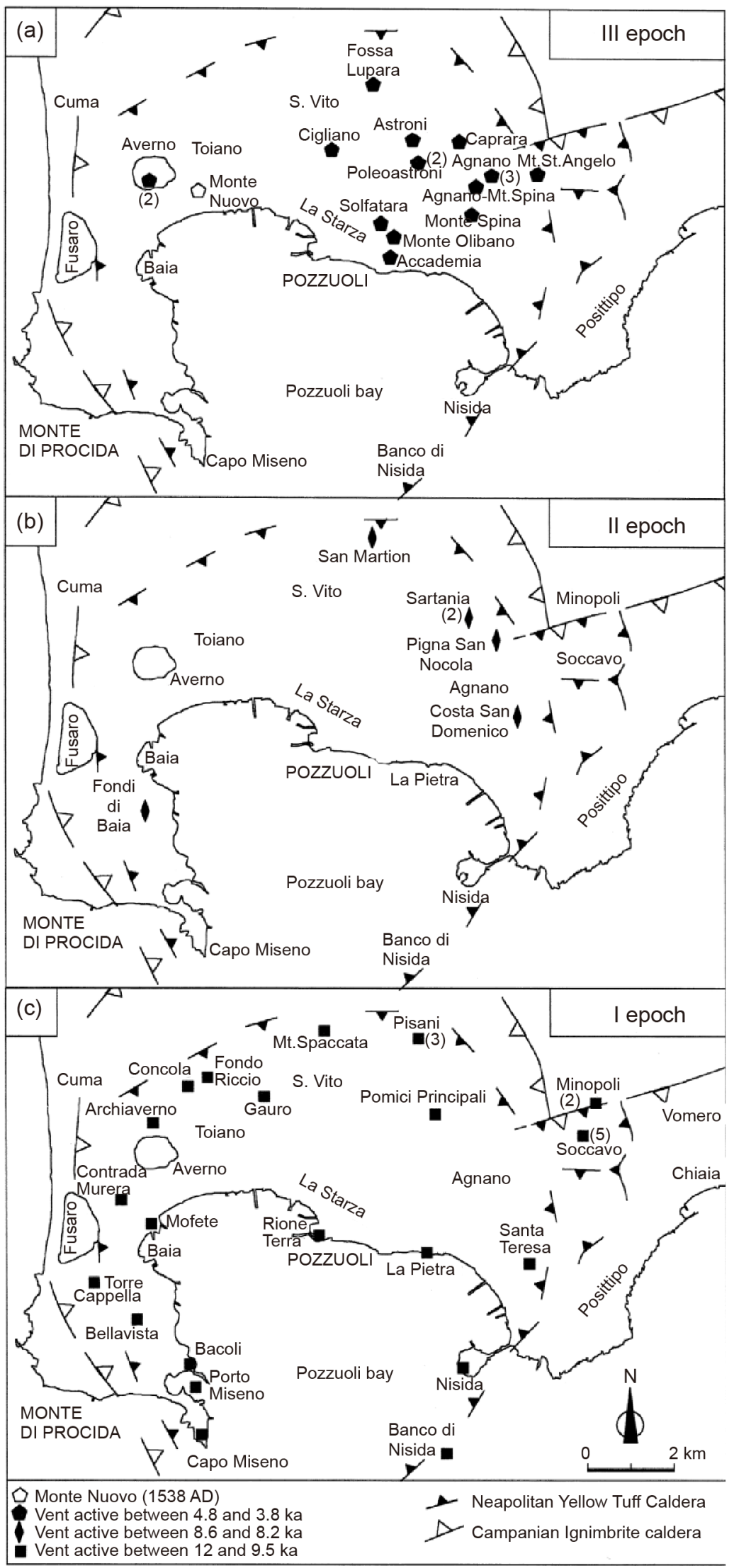

Figure 6. Location of the eruption in last 15 ka subdivided by Epochs (from [1]). 


\section{Reference Points Most Meaningful for Explaining the Bradyseism}

During the debate between Gradualism and catastrophism from Charles Lyell and James Hutton; Lyell had the brilliant idea to come in the Campi Flegrei to look the deformation where were shaped: The Serapeo, Macellum, Marketplace (Figure 7). He recognized that the three column were full of Lithophaga lithophaga living in intertidal level within the column, demonstrating that the land moved in two way (up-down versus time) slowly demonstrating gradualism was the geological process most important in geology. And at Campi Flegrei, the data on Serapeo can help to use Serapeo as gauge that measure the variations that give rise to the Bradyseism. The deformations in the last $15 \mathrm{ka}$ have coupled both magma (epoch) and fluid [19]. This has produced several geomorphic characters that are easily to ascertain. One important features is the resurgent block of Campi Flegrei, similar to those of Pantelleria Island (Montagna Grande) and in Ischia Island (Monte Epomeo) (Figures 8(a)-(c)) [20]. Furthermore, Parascandolo drew the deformation (Figure $8(\mathrm{~d})$ ) of the land with respect the sea that has been updated day by day from INGV-OV of Naples. The Serapeo was built in the year $1 \mathrm{AD}$, and then the pavement was invaded by sea water, so the Romans built two floors: ceramic and above it, marble pavement, from the Figure 9 it is clear that the upper floor appears on the column at $19 \mathrm{~m}$, while the first (ceramic) floor is at $3 \mathrm{mt}$. there are no evidence of Lithophaga lithophaga while the

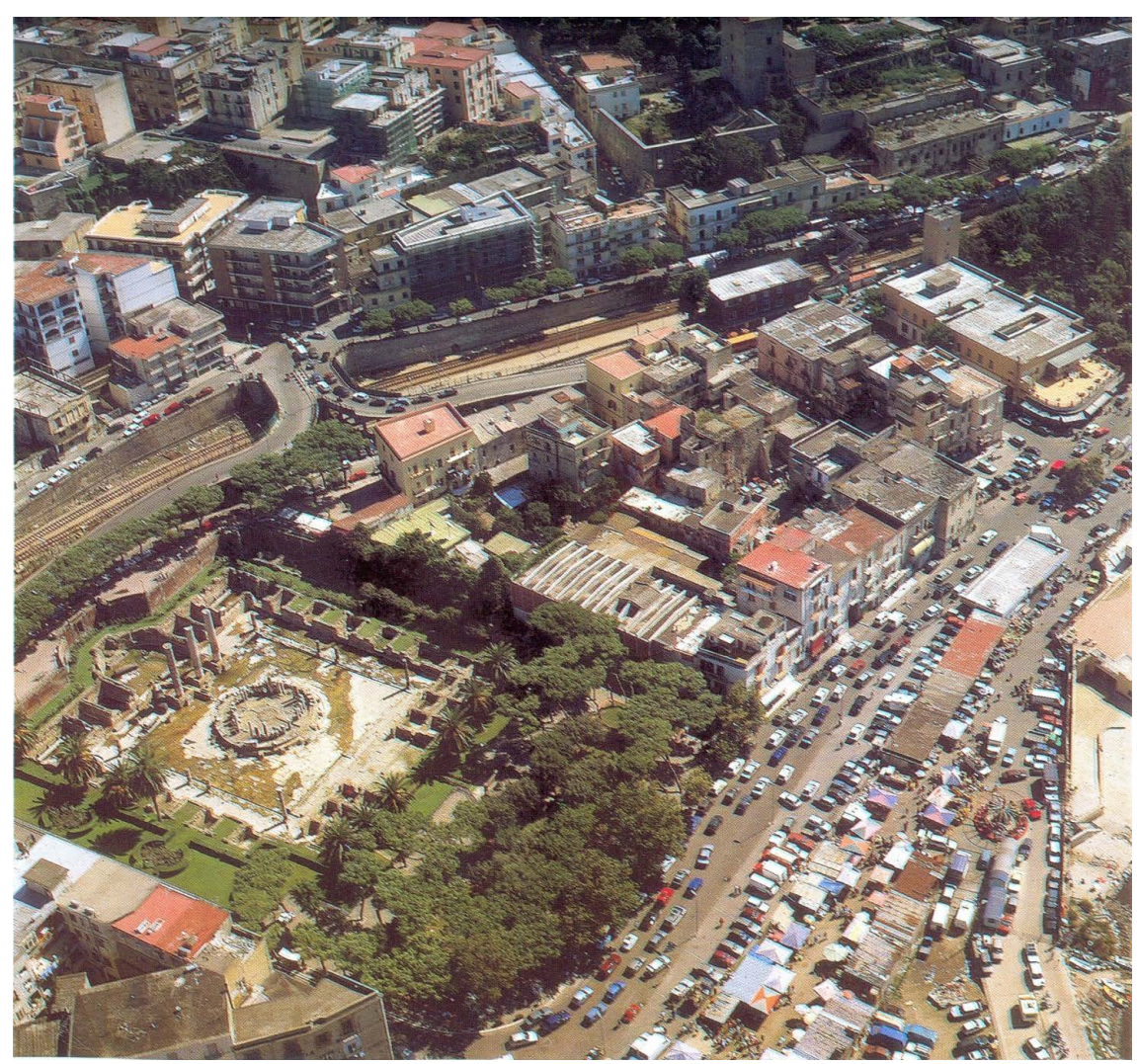

Figure 7. Serapeo as is seen nowadays by helicopter. 


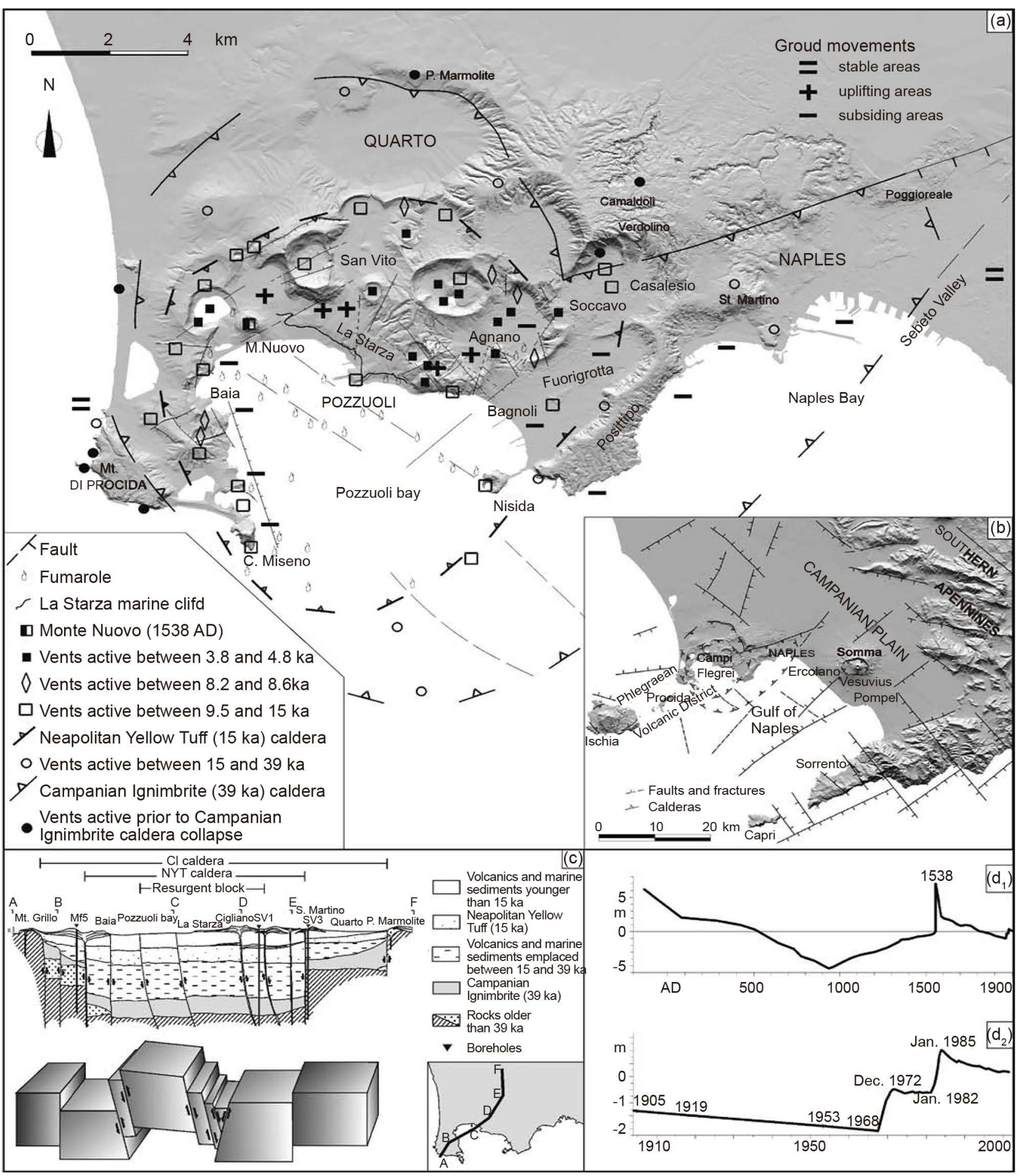

Figure 8. (a) Campi Flegrei DEM with the location of eruption and the deformation. (b) Structural map of the Campanian Plain. (c) Geological Section with a simplified of the resurgent block. (d) Parascandola curve. $D_{1}$ Deformation curve covering the last century(from [1]).

second $3 \mathrm{mt}$ are full of evidence of Lithophaga lithophaga (Figure 9) this imply that early in the last 2000 years, there was subsidence and a large ingression of the sea in Campi Flegrei, followed by uplift (Figure 10 and Figure 11). 

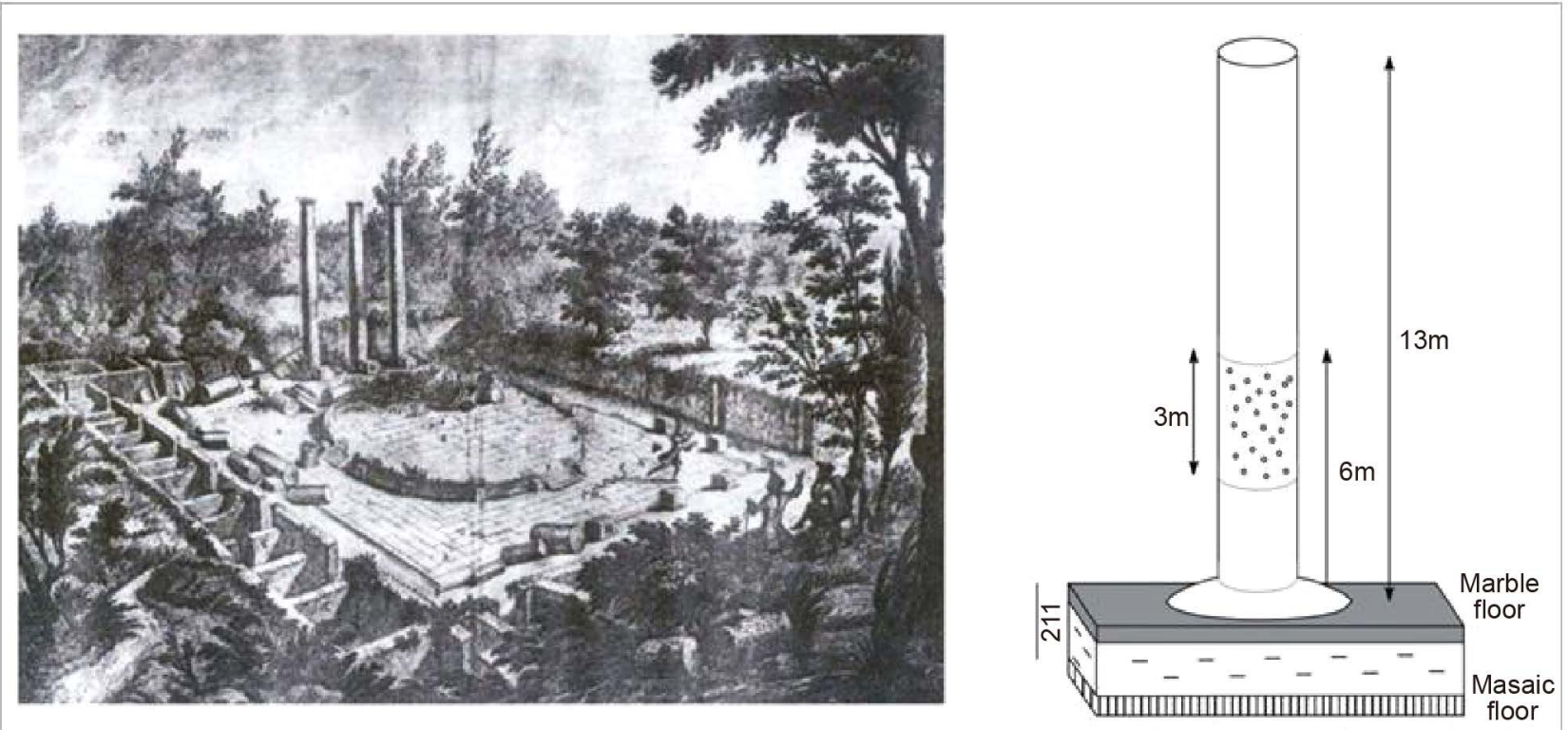

Figure 9. Serapeo during an uplift period probably before the eruption of Monte Nuovo volcano. Simplified figure how the Marble column were used by Lithophaga lithophaga.

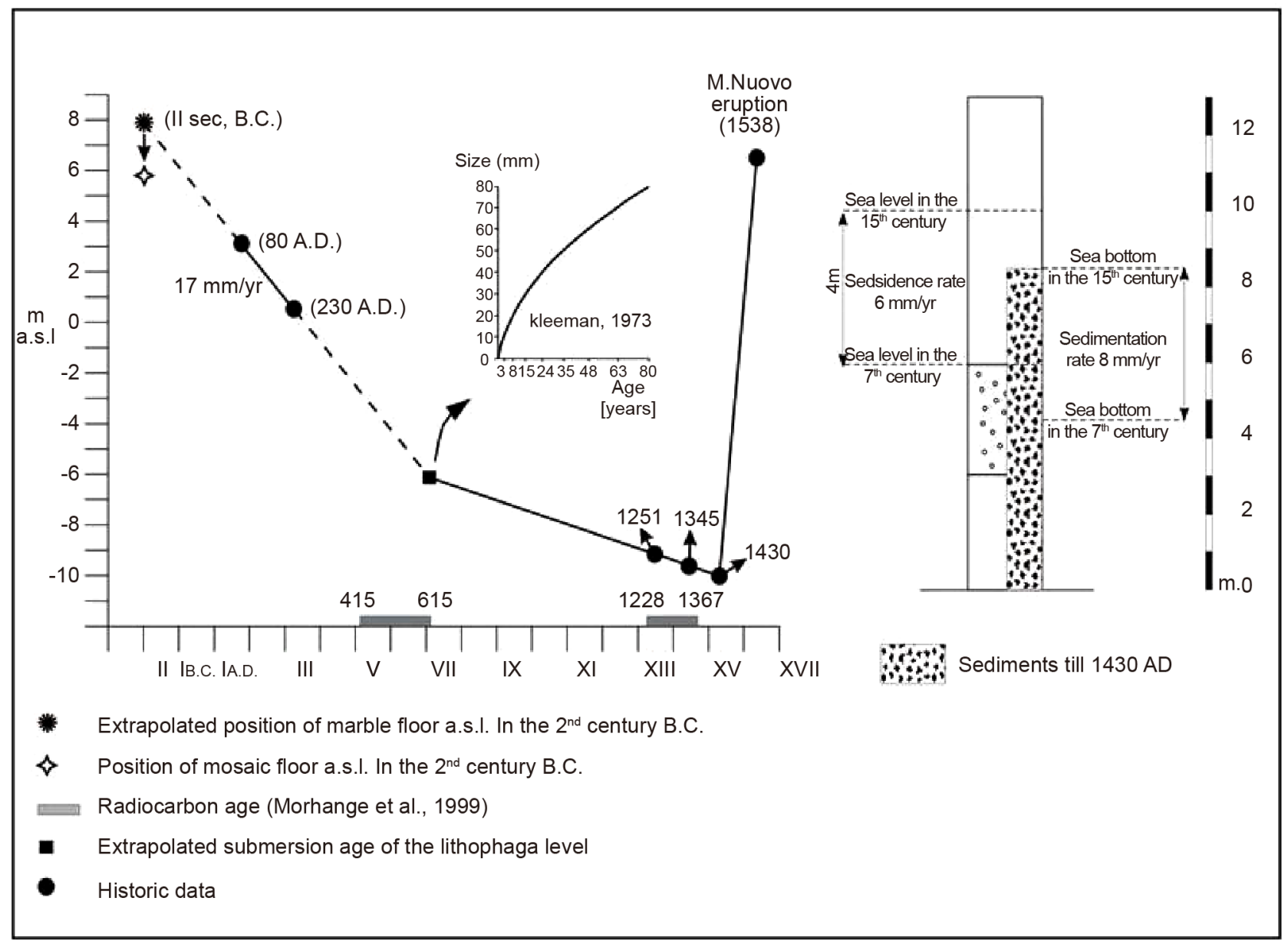

Figure 10. New view of the Parascadola curve. The curve has many points to support such a diagram (modified from [21] [23] [24]. 


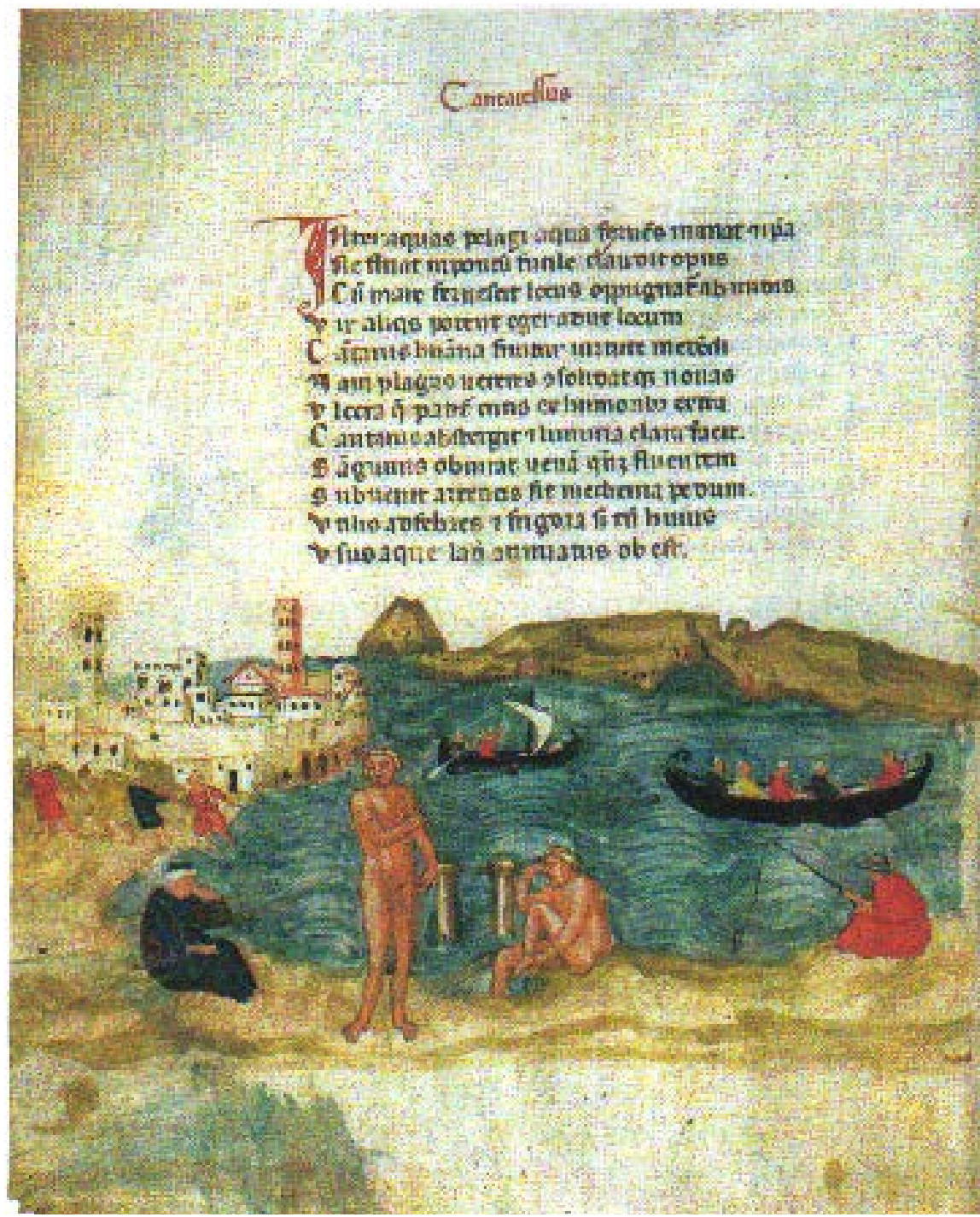

Figure 11. "La sorgente del Cantariello" 1430 show the column under the see at least of $10 \mathrm{mt}$ (from Scottish codex).

\section{Innovative Features on the Parascandola Modified Curve}

One feature that can be highlighted from the Serapeo (marble column) is that the land rose much faster before the eruption of Monte Nuovo. The point lowest of the new curve is 1430 as suggest some historical data and this is clear in the picture called "La sorgente di Cantariello" (from Scottish codex) (Figure 10, Figure 11). While the author was painting the marble column within the sea, he also showed that Serapeo had many hot springs. The range of time 1490-1538 is very short compared to the data of Parascandola. If this behavior is typical, a new Bradyseism could really lead to a new eruption. Of course, the magma volume will be under $1 \mathrm{Km}^{3}$ like the other ephemeral or short-lived eruptions in the last $15 \mathrm{ka}$. The most likely type of eruption will be monogenetic, phreatomagmatic, with only a low probability of a super-eruption. Actually, if we sum the land that rose in 1970-72 and 1983-84, with a new episode similar to 
1983-84, this last event could trigger an eruption but not a super-eruption.

\section{Subsidence of Campi Flegrei after the Eruption of Mt. Nuovo}

In Figure 12, The Santa Maria delle Grazie Church gives a view of Pozzuoli after the eruption of Mt. Nuovo. It is easy to see that the land was uplifted greatly around Monte Nuovo and nearby but then the area of the church had a different and fast subsidence. The subsidence can also be seen from Figure 13 where the "Ponte di Caligola" height range by painting to painting. In Figure 13, the diagram include all the points where subsidence was seen after the Monte Nuovo eruption and how the land subsidence continued until the Bradyseism of 1970-72 (Figure 14 and Figure 15). The points taken in study have also the same slope. Around 1945-1946 the church is invaded from water.

\section{Post-Caldera Structures (Post NYT)}

Figures 16-23 show monogenetic volcano: cinder cone, tuff cone, tuff ring, and Maar-lake as the Averno lake. There is also a dome where people built the Accademia Aureonatica. It is the only significant effusive feature.. Since the volumes of these volcanos are very low, they can be defined Ephemeral structures. From the paleogeography around $5 \mathrm{Ka}$, the land undergoes subsidence that produced a Marine Terrace, later uplifted to become La Starza cliff, along with

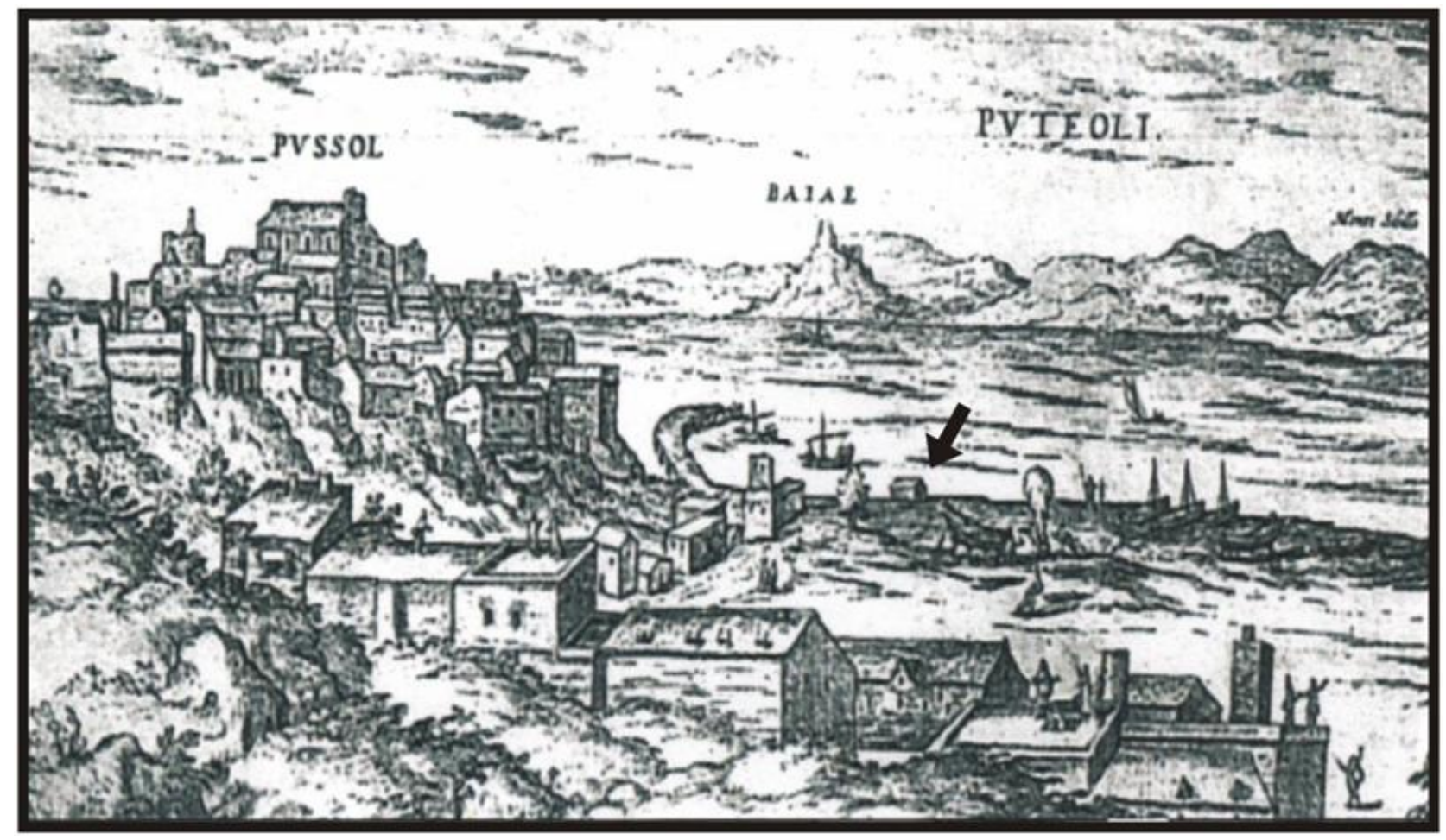

Figure 12. engraving where it is shown with an arrow S.M. delle Grazie Church (a point significant for the deformation after the eruption of Monte Nuovo. You can see also the "Ponte di Caligola" and Rione Terra the oldest structure in Pozzuoli, evacuated during the 1970-1972 seismic crises. 

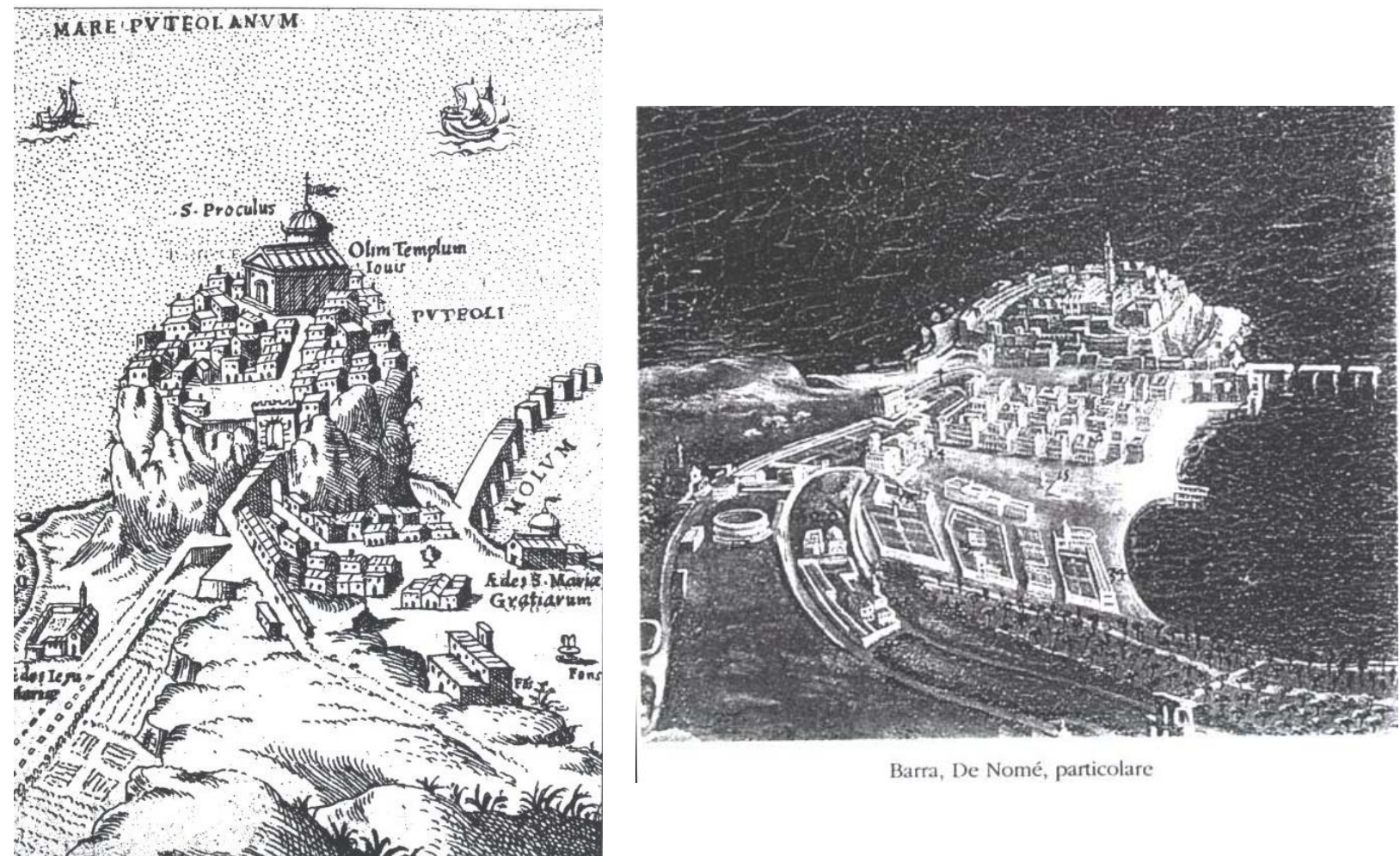

Barra, De Nomé, particolare
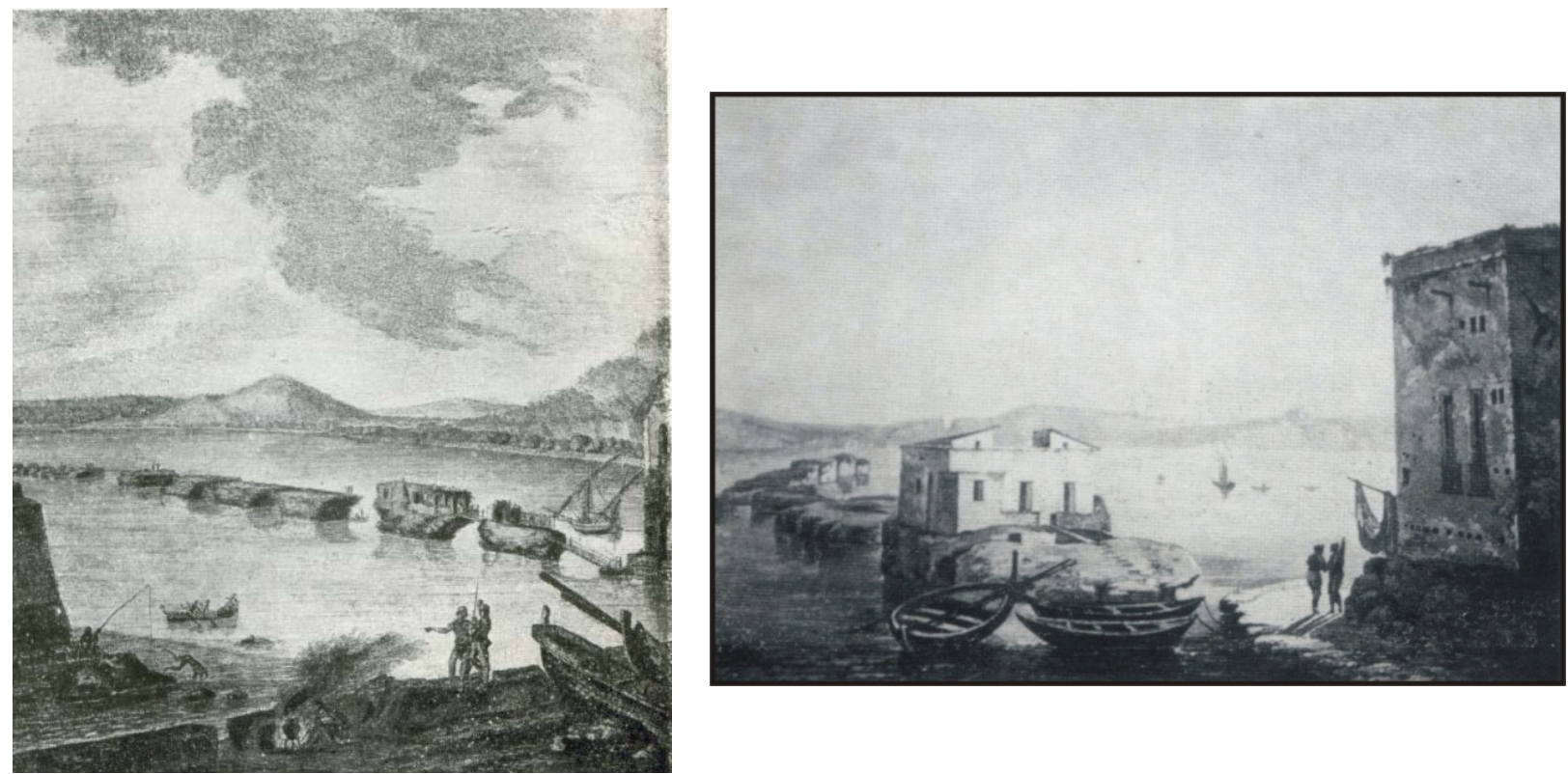

Figure 13. Four pictures that show how the ponte di Caligola varied its position subsideding after the eruption of Monte Nuovo.

flat land that starts near the sea and goes until Quarto volcano. Figure 18 shows very well this geomorphic characteristic, and also Romans ruins (Porto julius) under the sea level from Pozzuoli to Baia which are a touristic attraction and suggest how the caldera floor during the Roman period was higher than it is now. Probably, there are also fault especially along Bacoli and the sea to maintain stable this area (Figure 19-23). 


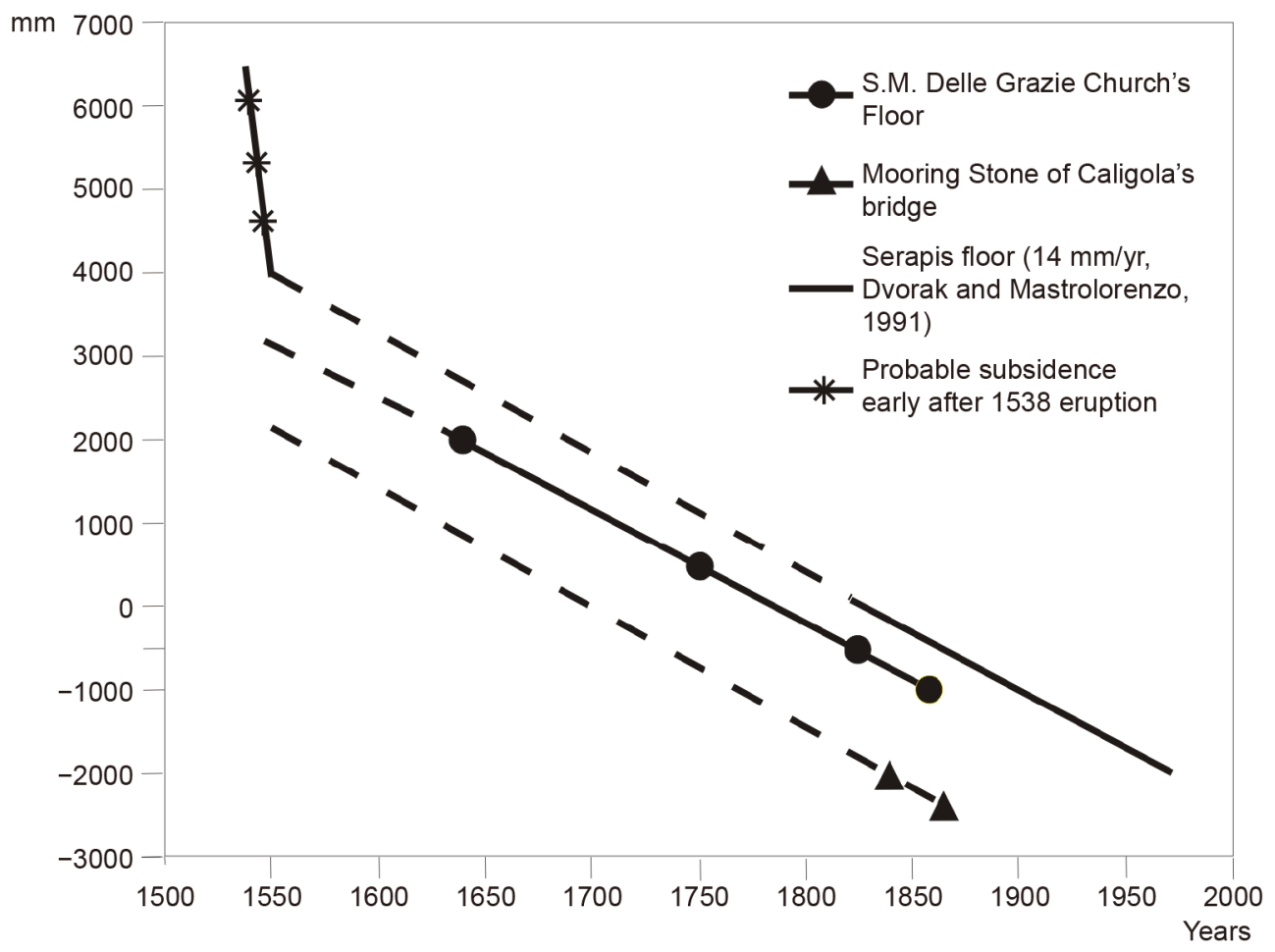

Figure 14. New diagram with the reference point showing the subsidence of Campi Flegrei after the eruption of Monte Nuovo [22].

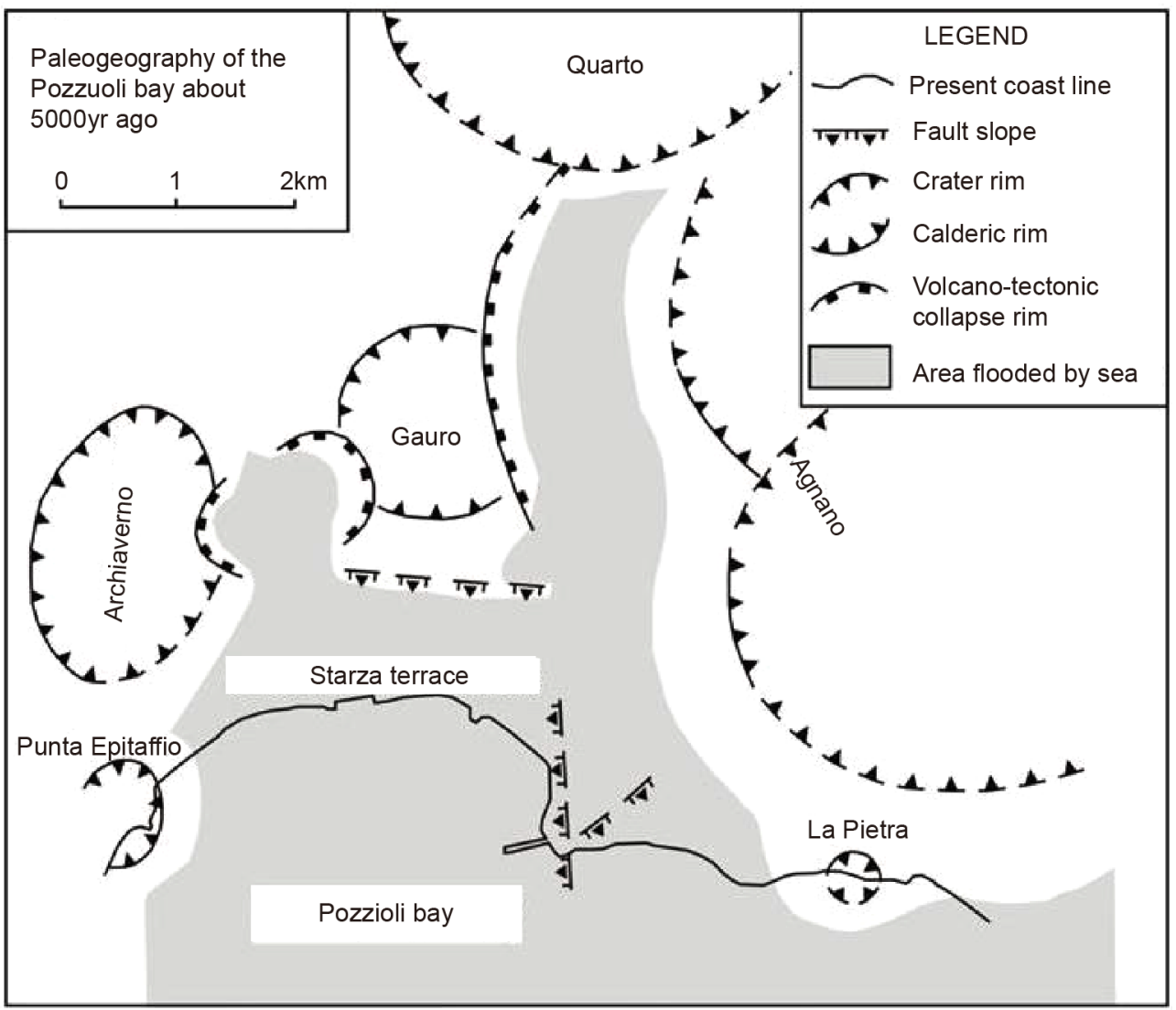

Figure 15. Paleogeography of Pozzuoli bay around 5 Ka ago. 


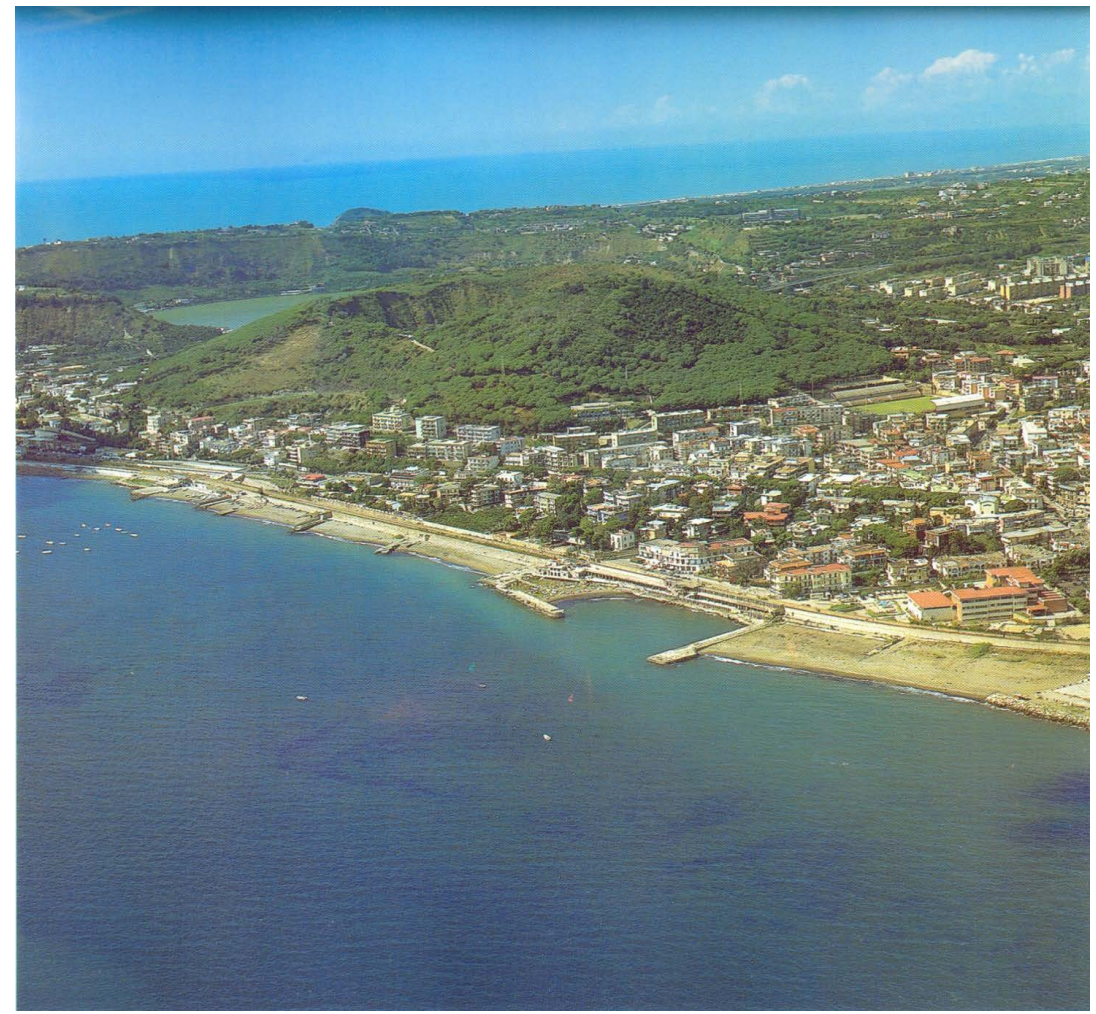

Figure 16. Monte Nuovo Cinder cone, with Averno lake maar behind it, nested in the older Archiaverno tuff ring. Averno lake was named as "the entrance of hell" during the Roman times, plus this locality is also famous for the legend of "Sibilla".

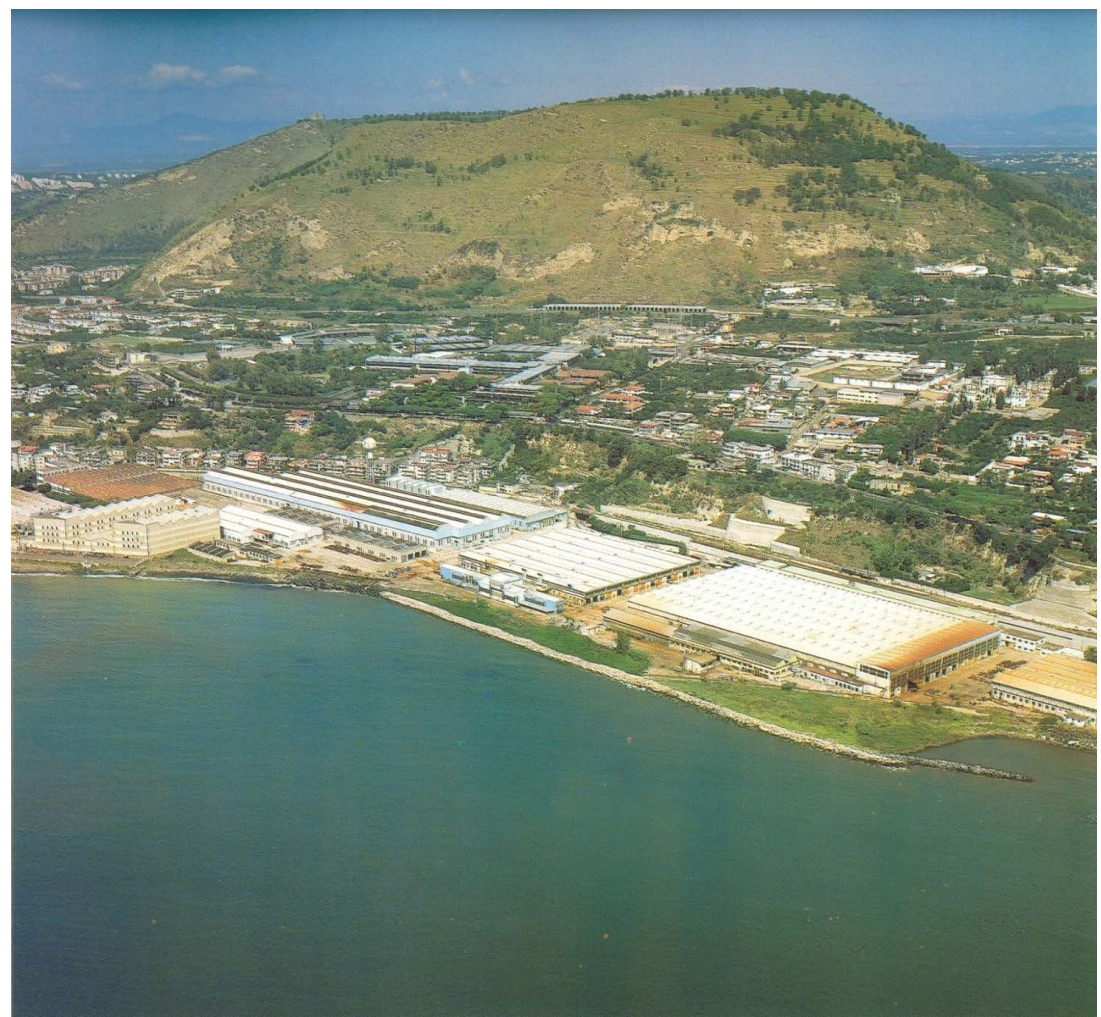

Figure 17. Gauro Volcano with the Marine Starza Terrace at its foot. 


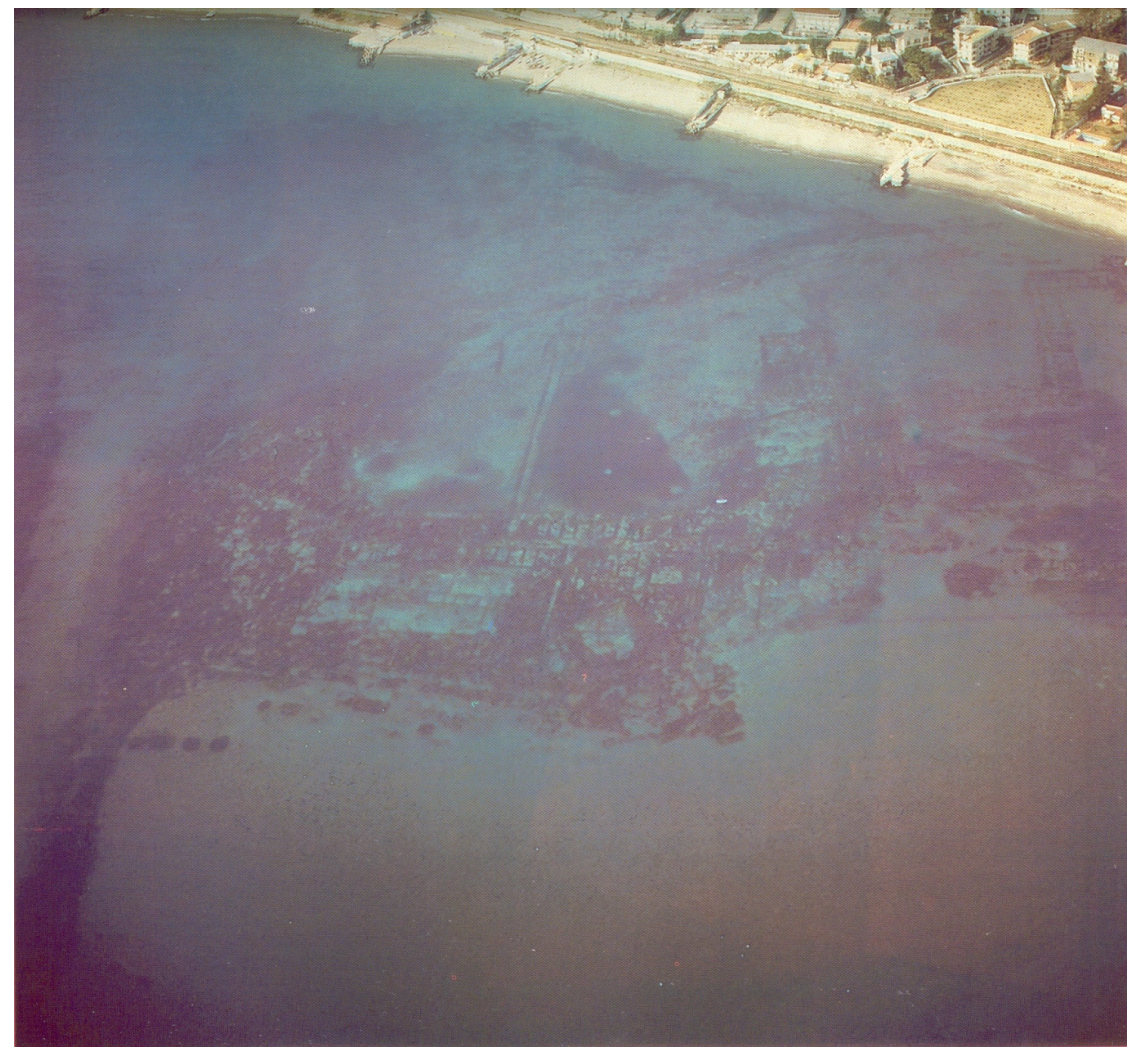

Figure 18. Portos Julius still submerged.

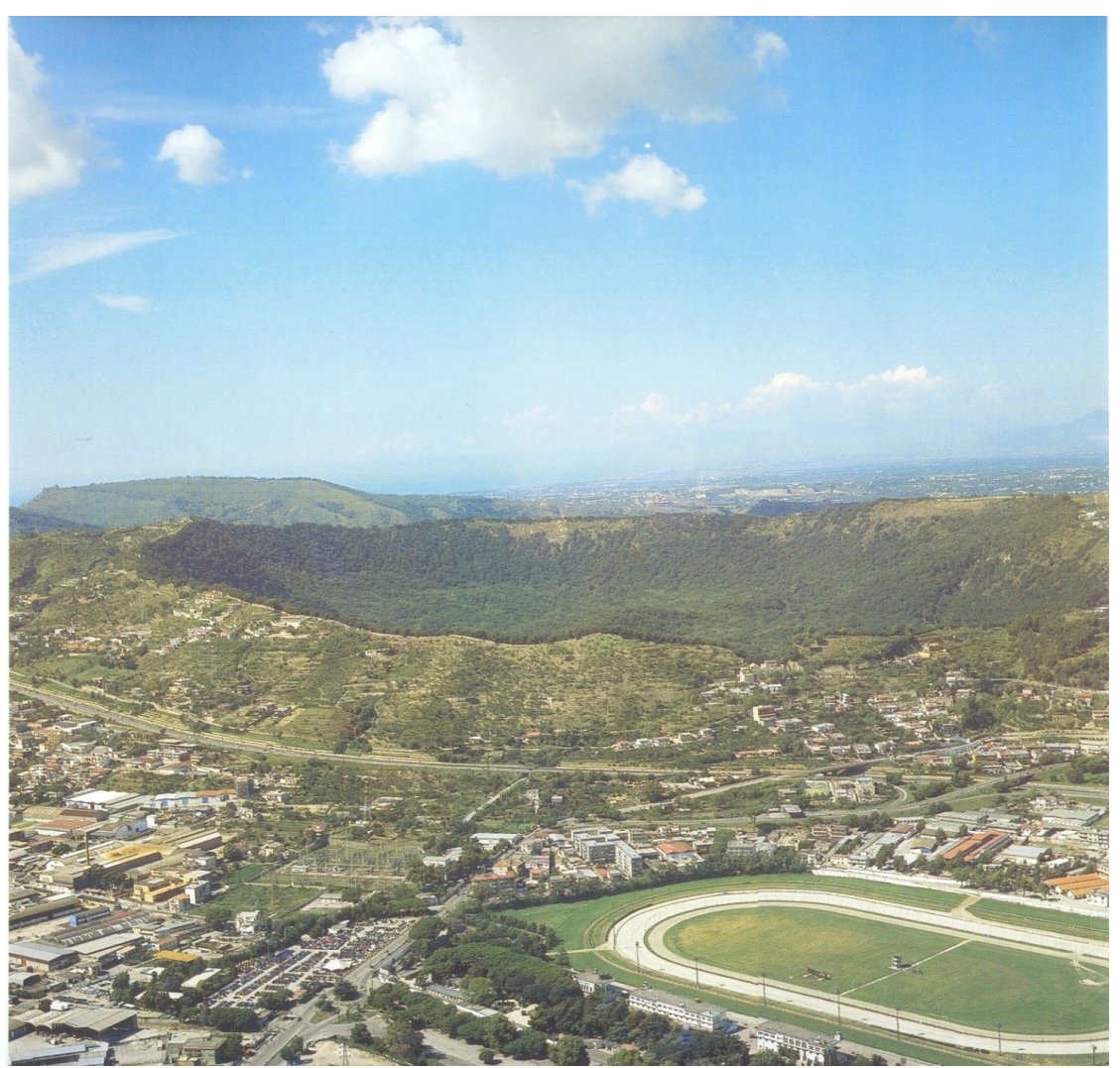

Figure 19. Volcano Astroni. Now, reserve of WWF. 


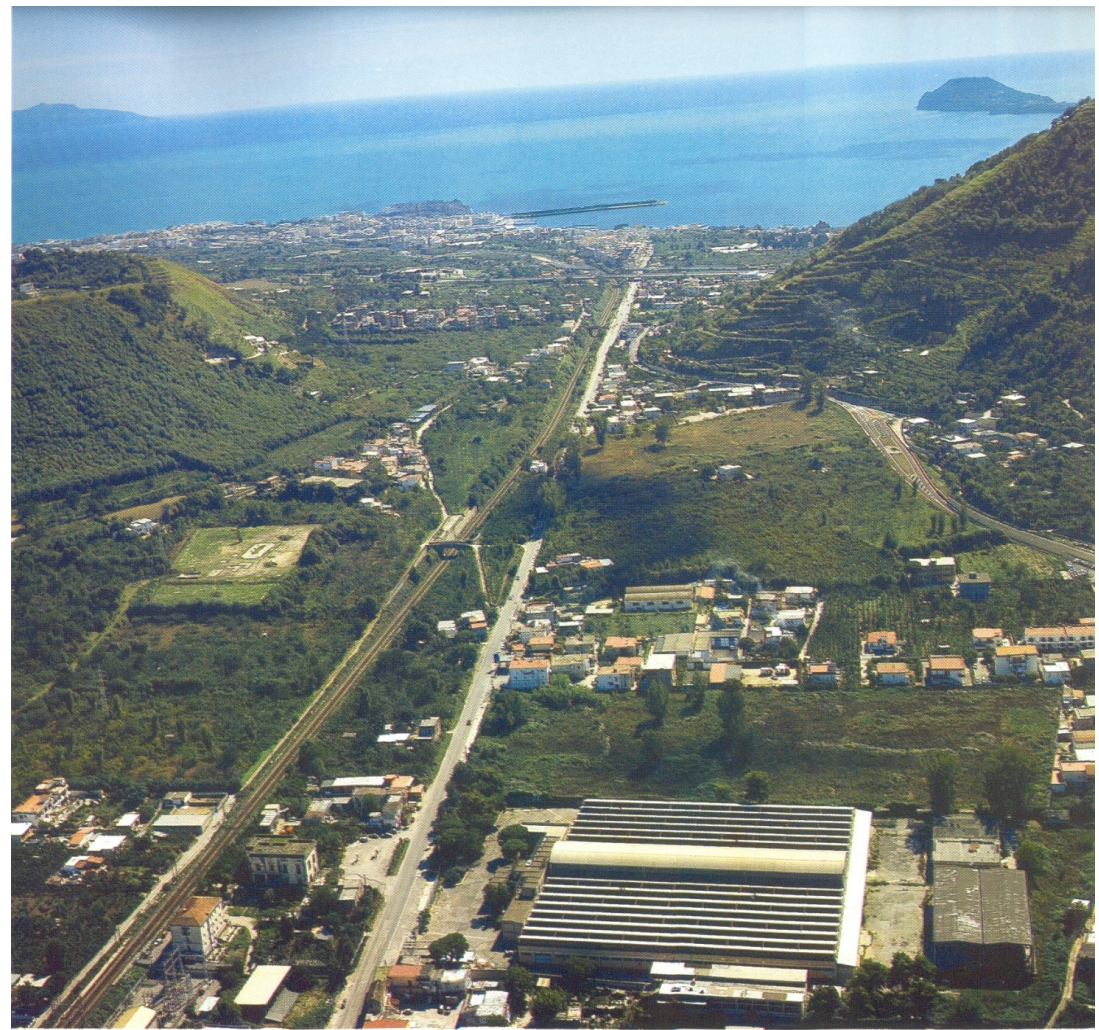

Figure 20. Between the Cigliano volcano (cinder Cone) and Gauro volcano (tuff cone). The flat floor tells us of the ingression of sea $5 \mathrm{Ka}$.

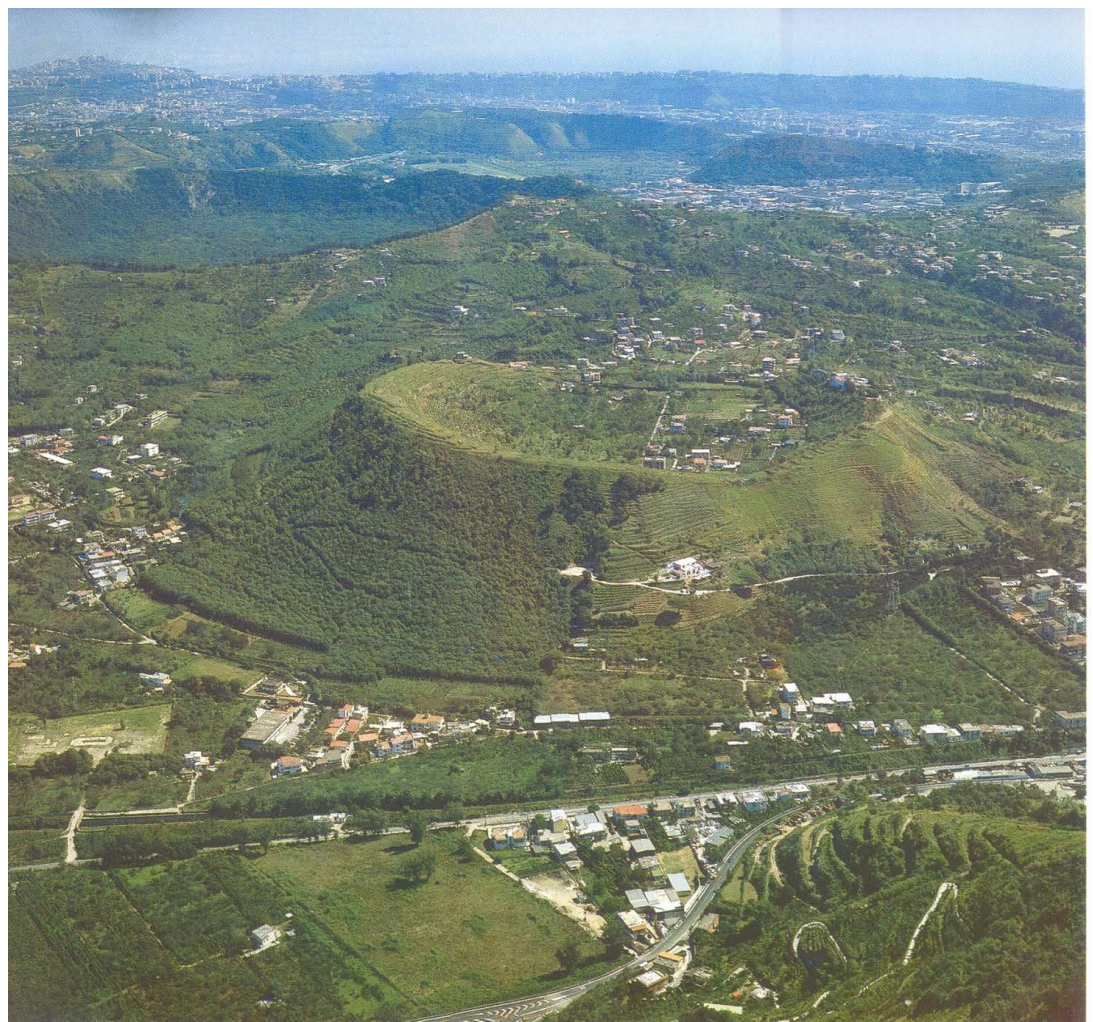

Figure 21. Cigliano volcano with Astroni and Agnano Monte Spina on the back. 


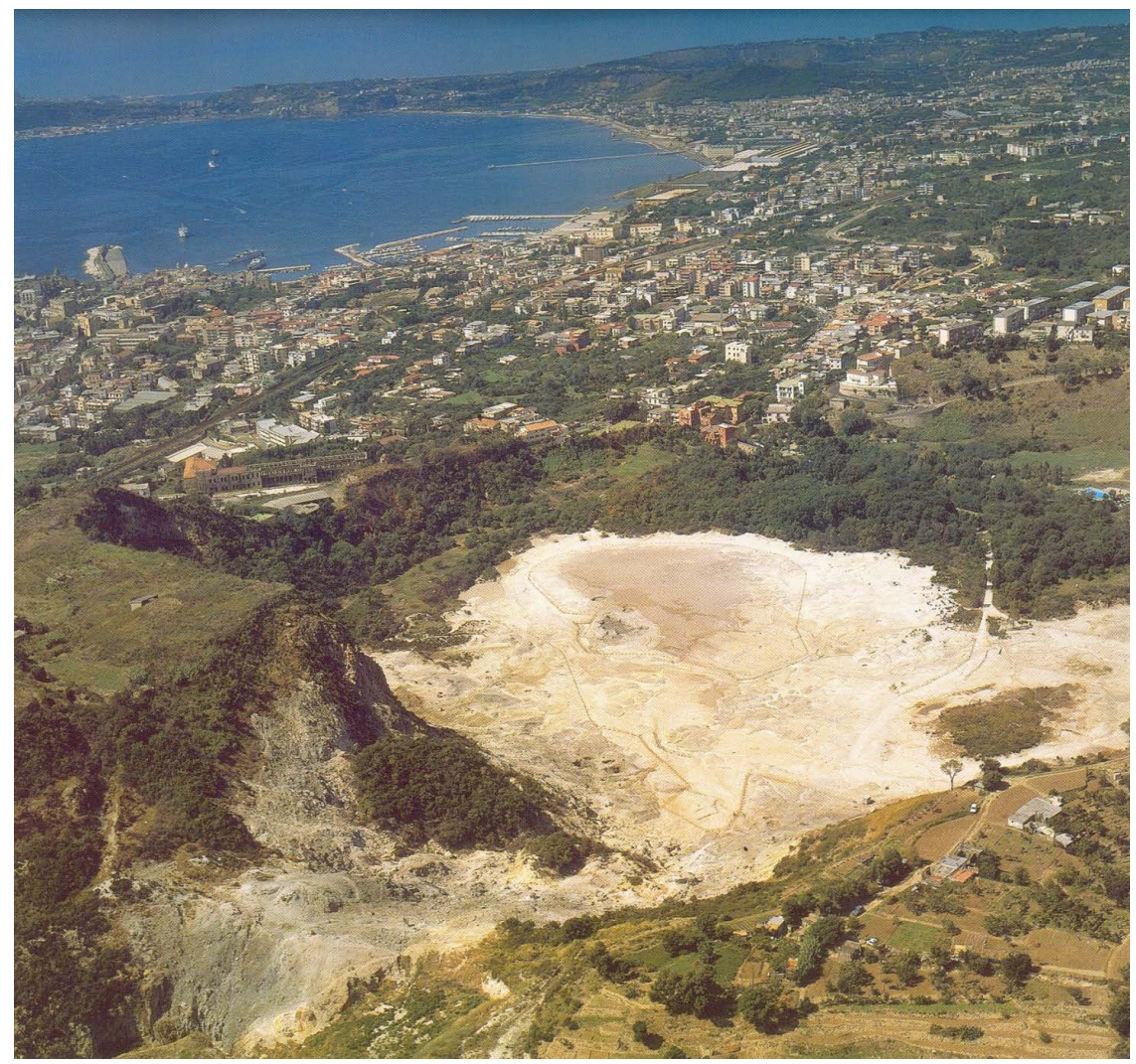

Figure 22. Solfatara Volcano (tuff ring) with numerous hot springs.

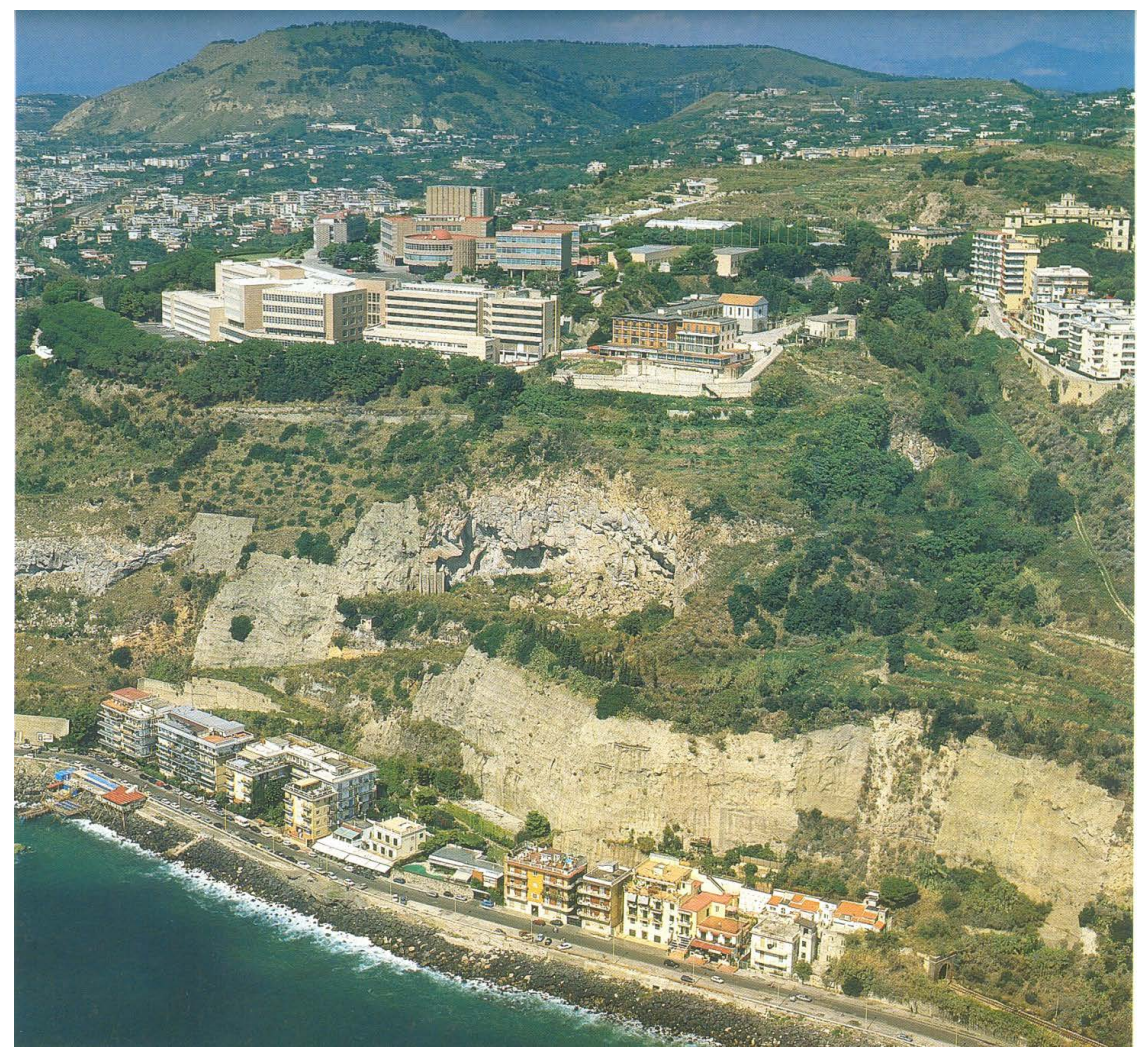

Figure 23. La Pietra volcano with above the lava dome (Accademia Aeronatica). 


\section{Conclusion}

Changes in structure, volume, deformation in the last 15 ka show the history of eruptions and unrest at Campi Flegrei. Campi Flegrei is monitored by INGV-OV and already under attention with yellow color. If more magma or/and fluid can rise, which can open a window and force its way out, it will be very dangerous, especially if the magma will come out in the sea that could produce more violence with the diluted currents. One particularly risky area is Via Napoli-Rione Terra. Some scientists have already noted that this was the focus of maximum uplift during 1983-84 and had a high concentration of epicentre quakes. This can be the next point of eruption, although not of great intensity like the CI and NYT. The paper reasoning suggests that such scenario can be real: the Monte Nuovo eruption can have started a new Epoch.

\section{Acknowledgements}

Chris Hawkesworth and Chris Newhall are thanked for an early review of the manuscript.

\section{References}

[1] Orsi, G., Di Vito, M.A. and Isaia, R. (2004) Volcanic Hazard Assessment at the Restless Campi Flegrei Caldera. Bulletin of Volcanology, 66, 514-530. https://doi.org/10.1007/s00445-003-0336-4

[2] Orsi, G., Di Vito, M. and Isaia, R. (1998) Volcanic Hazards and Risk in the Parthenopean Megacity.

[3] Paone, A. (2013) Petrogenesis of Trachyte and Rhyolite Magmas on Ponza Island (Italy) and Its Relationship to the Campanian Magmatism. Journal of Volcanology and Geothermal Research, 267, 15-29. https://doi.org/10.1016/j.jvolgeores.2013.09.008

[4] Torrente, M.M. and Milia, A. (2013) Volcanism and Faulting of the Campania Margin (Eastern Tyrrhenian Sea, Italy): A Three-Dimensional Visualization of a New Volcanic Field off Campi Flegrei. Bulletin of Volcanology, 75, 719-732. https://doi.org/10.1007/s00445-013-0719-0

[5] Lima, A., De Vivo, B., Spera, F.J., Bodnar, R.J., Milia, A., Nunziata, C.E., Belkin, H. and Cannatelli, C. (2009) Thermodynamic Model for Uplift and Deflation Episodes (Bradyseism) Associated with Magmatic-Hydrothermal Activity at the Campi Flegrei (Italy). Earth-Science Reviews, 97, 44-58. https://doi.org/10.1016/j.earscirev.2009.10.001

[6] De Lorenzo (1904) The History of Volcanic Action in the Phlegraean Fields.

[7] Rittmann, A. (1950) Geological Summary of Campi Flegrei. Bollettino della Società Geologica Italiana, 69, 117-177.

[8] Scherillo, A. and Franco, E. (1960) Stratigraphic Survey of Neapolitan Municipality. Bollettino della Società dei naturalisti in Napoli, 69, 255-262.

[9] Di Girolamo, P., Ghiara, M.R., Lirer, L., Rolandi, G. and Stanzione, D. (1984) Vulcanology and Petrology of Campi Flegrei. Bollettino della Società Geologica Italiana, 103, 349-413.

[10] Rosi, M. and Sbrana, A. (1987) Phlegraean Fields: Quaderni de La Ricerca Scientifica. Consiglio Nazionale delle Ricerche Monograph 114, Volume 9, 175 p. 
[11] Di Vito, M.A., Isaia, R., Orsi, G., Southon, J., de Vita, S., D’Antonio, M., Pappalardo, L. and Piochi, M. (1999) Volcanism and Deformation since 12,000 Years at the Campi Flegrei Caldera (Italy). Journal of Volcanology and Geothermal Research, 91, 221-246. https://doi.org/10.1016/S0377-0273(99)00037-2

[12] De Vivo, B., Rolandi, G., Gans, P.B., Calvert, A., Bohrsom, W.A., Spera, F.J. and Belkin, H.E. (2001) New Constraints on the Pyroclastic Eruptive History of the Campanian Volcanic Plain (Italy). Mineralogy and Petrology, 73, 47-65. https://doi.org/10.1007/s007100170010

[13] Deino, A.L., Orsi, G., de Vita, S. and Piochi, M. (2004) The Age of the Neapolitan Yellow Tuff Caldera-Forming Eruption (Campi Flegrei Caldera Italy) Assessed by 40Ar/39Ar Dating Method. Journal of Volcanology and Geothermal Research, 133, 157-170. https://doi.org/10.1016/S0377-0273(03)00396-2

[14] Costa, A., Folch, A., Macedonio, G., Giaccio, B., Isaia, R. and Smith, V.C. (2012) Quantifying Volcanic Ash Dispersal and Impact of the Campanian Ignimbrite Super-Eruption. Geophysical Research Letters, 39, L10310.

[15] Engwell, S.L., Sparks, R.S.J. and Carey, S. (2017) Physical Characteristics of Tephra Layers in the Deep Sea Realm: The Campanian Ignimbrite Eruption. Geological Society, London.

[16] Annen, C. and Sparks, R.S.J. (2002) Effects of Repetitive Emplacement of Basaltic Intrusions on Thermal Evolution and Melt Generation in the Deep Crust. Earth and Planetary Science Letters, 203, 937-955. https://doi.org/10.1016/S0012-821X(02)00929-9

[17] Paone, A. (2006) The Geochemical Evolution of the Mt. Somma-Vesuvius Volcano. Mineralogy and Petrology, 87, 53-80. https://doi.org/10.1007/s00710-005-0103-7

[18] Pappalardo, L., Piochi, M., D’Antonio, M., Civetta, L. and Petrini, R. (2002) Evidence for Multi Stage Magmatic Evolution during the Past $60 \mathrm{kyr}$ at Campi Flegrei (Italy) Deduced from $\mathrm{Sr}, \mathrm{Nd}$, and $\mathrm{Pb}$ Isotope Data. Journal of Petrology, 43, 1415-1434. https://doi.org/10.1093/petrology/43.8.1415

[19] Bodnar, R.J., Cannatelli, C., De Vivo, B., Lima, A.M., Belkin, E.H. and Milia, A. (2007) Quantitative Model for Magma Degassing and Ground Deformation (Bradyseism) at Campi Flegrei, Italy: Implications for Future Eruptions. Geeology, 35, 791-794. https://doi.org/10.1130/G23653A.1

[20] Orsi, G., Gallo, G. and Zanchi, A. (1991) Simple Shearing Block Resurgence in Caldera Depressions. A Model from Pantelleria and Ischia. Journal of Volcanology and Geothermal Research, 47, 1-11. https://doi.org/10.1016/0377-0273(91)90097-J

[21] Bellucci, F., Woo, J., Kilburn, R.J. and Rolandi, G. (2006) Ground Deformation at Campi Flegrei, Italy: Implications for Hazard Assessment. In: Troise, C., De Natale, G. and Kilburn, C.R.J., Eds., Mechanisms of Activity and Unrest at Large Calderas, Geological Society, London, 269. https://doi.org/10.1144/GSL.SP.2006.269.01.09

[22] Dvorak, J.J. and Mastrolorenzo, G. (1991) The Mechanisms of Recent Vertical Crustal Movements in Campi Flegrei Caldera, Southern Italy. Geological Society of America Special Paper 263, 47 p.

[23] Morhange, C., Marriner, N., Laborel, J., Todesco, M. and Oberlin, C. (2006) Rapid Sea-Level Movements and Non Eruptive Crustal Deformations in the Phlegrean Fields Caldera, Italy. Geology, 34, 93-96. https://doi.org/10.1130/G21894.1

[24] Kleemann, K.H. (1973) Lithophaga lithophaga (L.) (Bivalvia) in Different Limestone. Malacologia, 14, 345-347. 